\title{
Impact of Topography on Groundwater Salinization Due to
}

\section{Ocean Surge Inundation}

Xuan Yu ${ }^{1}$, Jie Yang ${ }^{2}$, Thomas Graf ${ }^{3}$, Mohammad Koneshloo ${ }^{1}$, Michael A. O’Neal ${ }^{1}$, Holly A. Michael $^{1,4 *}$

1. Department of Geological Sciences, University of Delaware, Newark DE 19716, USA.

2. Department of Hydrogeology, Helmholtz-Centre for Environmental Research GmbH UFZ, Permoserstraße 15, 04318 Leipzig, Germany

3. Institute of Fluid Mechanics and Environmental Physics in Civil Engineering, Leibniz Universität Hannover, Appelstrasse. 9A, 30167 Hannover, Germany

4. Department of Civil \& Environmental Engineering, University of Delaware, Newark DE 19716, USA.

*Corresponding Author, hmichael@udel.edu

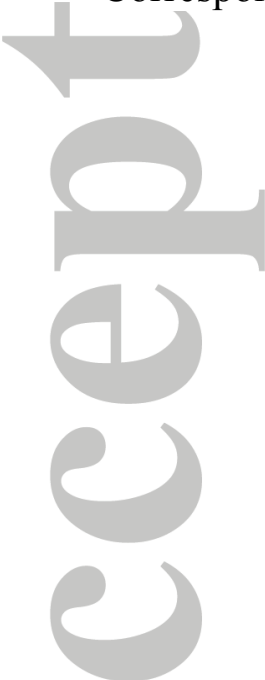

This article has been accepted for publication and undergone full peer review but has not been through the copyediting, typesetting, pagination and proofreading process which may lead to differences between this version and the Version of Record. Please cite this article as an 'Accepted Article', doi: 10.1002/2016WR018814 


\section{Abstract}

Sea-level rise and increases in the frequency and intensity of ocean surges caused by climate change are likely to exacerbate adverse effects on low-lying coastal areas. The landward flow of water during ocean surges introduces salt to surficial coastal aquifers and threatens groundwater resources. Coastal topographic features (e.g., ponds, dunes, barrier islands, and channels) likely have a strong impact on overwash and salinization processes, but are generally highly simplified in modeling studies. To understand topographic impacts on groundwater salinization, we modeled a theoretical overwash event and variable-density groundwater flow and salt transport in 3D using the fully coupled surface and subsurface numerical simulator, HydroGeoSphere. The model simulates the coastal aquifer as an integrated system considering overland flow, coupled surface and subsurface exchange, variably saturated flow, and variable-density groundwater flow. To represent various coastal landscape types, we simulated both synthetic fields and real-world coastal topography from Delaware, USA. The groundwater salinization assessment suggested that the topographic connectivity promoting overland flow controls the volume of aquifer that is salinized. In contrast, the amount of water that can be stored in surface depressions determines the amount seawater that infiltrates the subsurface and the time for seawater to flush from the aquifer. Our study suggests that topography has a significant impact on groundwater salinization due to ocean surge overwash, with important implications for coastal land management and groundwater vulnerability assessment.

Keywords: Ocean surge, HydroGeoSphere, groundwater, salinization, topography

\section{Introduction}

Climate change and sea-level rise affect densely populated coastal zones not only in life and infrastructure but also in water resources [Taylor et al., 2013; Day et al., 2007; Rabbani et al., 2013; Nicholls and Cazenave, 2010]. Coastal groundwater resources can be affected by lateral seawater intrusion [Ferguson and Gleeson, 2012; Rotzoll and Fletcher, 2013] and vertical infiltration during ocean surge (tsunami, storm surge) inundation [Anderson $J r, 2002]$. Because groundwater salinization is a long and gradual process, it has received little attention in vulnerability assessments relative to surface water and infrastructure [Törnqvist and Meffert, 2008]. From the perspective of groundwater sustainability, process understanding and 
assessment of potential effects of salinization on groundwater resources are critical for improving water resource resilience [Werner et al., 2013].

There have been many studies focusing on lateral seawater intrusion induced by sea-level rise [Ataie-Ashtiani et al., 2013; Ketabchi et al., 2016; Morgan et al., 2015; Masterson et al., 2014; Werner et al., 2013; Michael et al., 2013; Werner and Simmons, 2009; Delsman et al., 2014], while relatively fewer studies have focused on vertically infiltrated seawater. Michael et al. [2013] pointed out that ocean surge inundation has the potential to severely salinize the coastal subsurface where a thick unsaturated zone exists. Holding and Allen [2015a] showed that while lateral saltwater intrusion due to sea-level rise was not a significant threat on Andros Island in the Bahamas, the associated extreme high tides and storm surge overwash can result in severe groundwater salinization due to vertical infiltration. Yu et al. [2010] suggested that the impacts of coastal inundation and extent of storm surges is of greater concern for groundwater salinization than classical lateral seawater intrusion at coastal aquifers in Bangladesh. Taylor et al. [2013] indicated that many coastal aquifers are expected to be more severely affected by storm surge overwash than by lateral intrusion. In low-lying coastal areas, overwash salinization can be severely exacerbated by even a small increase in sea level or high tide elevation [Little et al., 2015; Passeri et al., 2015]. Further, the severity and extent of salinization due to overwash events depend on the frequency and intensity of ocean surges [Yu et al., 2010], which are predicted to increase with climate change [Church et al., 2013]. Therefore, saltwater infiltration into fresh aquifers due to ocean surge inundation, together with groundwater salinization and recovery, should be considered in synergetic studies to improve the assessment and management of coastal freshwater resources under climate change [Passeri et al., 2015]. 
Several previous studies have demonstrated the critical impacts of vertical salinization with numerical modeling. In these studies, the surge flooding is modeled by either specifying an infiltration flux or applying a constant head boundary to the land surface for a specified period of time. Chui and Terry [2013] applied a 2-m head boundary condition at the surface of a topographic depression during the 10-h overwash event to approximate surface water inundation. Holding and Allen [2015a] assumed a gradual, linear increase in flood level followed by a constant maximum level for 2 hours. Bailey [2015] assumed different depths and duration of inundation to describe different overwash events. These studies shed light on the subsurface salinization processes, but the simplified boundary condition masks the impacts of land surface. In reality, the temporal dynamics of inundation height is tightly coupled to topography [Ramsey et al., 2011]. Neglecting topographic features could therefore introduce considerable uncertainty in simulated saltwater infiltration [Holding and Allen, 2015a].

Three scales of topography were defined by McDonnell [2013]. Microtopography refers to small depressions with correlation length scales on the order of centimeters to meters. Effects of microtopography are usually parameterized as Manning's roughness coefficient or conceptual representations of overland flow obstructions [Frei and Fleckenstein, 2014]. Rainfall-runoff studies indicated that microtopographic depressions have significant effects on overland flow generation by increasing infiltration [Thompson et al., 2010; Frei et al., 2010; Le and Kumar, 2014]. Similarly, microtopographic depressions are expected to increase saline water infiltration by enhancing retention of saltwater during inundation. Mesotopography refers to landscape-scale features and engineered structures with correlation length scales of meters to kilometers, e.g., ponds, dunes, barrier islands, and channels. Sawyer et al. [2015] found that mesoscale landforms are one of the major controlling factors in surface water-groundwater exchange and solute 
retention. Macrotopography refers to the overall topographic gradient. Macrotopography is explicitly represented in coastal groundwater models as beach slopes, and has been shown to be important in freshwater-seawater interaction [Zhou et al., 2014; Qu et al., 2014; Ketabchi et al., 2016].

It is clear that macrotopography has an important control on flooding, and effects of microtopography can be captured by adjusting roughness parameters. However the effects of mesotopography on groundwater salinization due to ocean surge inundation are not well known. Only a few studies have considered mesotopography, but those that have indicate that it plays an important role. Terry and Falkland [2010] monitored groundwater salinity over a 2-year poststorm period. Their data showed that stagnant seawater in swamps was a continuous source of aquifer salinization. Yang et al. [2015b] used a variable-height dyke to simulate the inland ponding of seawater during storm inundation. The results suggested that groundwater salinization in the coastal aquifer was dependent on the extent of the ponded area. Chui and Terry [2012] used trapezoidal depressions to represent the local topography of inland swamps. The simulations suggested that the depressions could prolong seawater stagnation and cause additional seawater infiltration along the swamp. Holding and Allen [2015a] used a rectangular channel on a flat surface domain to represent the topographic depressions of trench-based wellfields. The simulation explicitly demonstrated the spatial and temporal development of a salt plume under the trench following a storm surge overwash event.

Conceptually, the effects of mesotopography can be illustrated as in Figure 1. During an ocean surge runup, saltwater is transported over the top of a coastal aquifer and infiltrates into the subsurface where it can percolate downward to the freshwater aquifer (runup, Figure 1a), After reaching the maximum horizontal flood extent (i.e. inundation line), some of the surface water 
flows back to the sea during the rundown process (rundown, Figure 1b). The rest infiltrates or is retained on the surface, eventually infiltrating into the subsurface or evaporating to the atmosphere, leaving high salt concentrations behind. It may take days to months for the saltwater to percolate through the unsaturated zone and mix with shallow groundwater [Terry and Falkland, 2010; Holding and Allen, 2015b]. Then, the saline groundwater can be flushed out due to the hydraulic gradient from land to sea, a process that can take many years to decades [Vithanage et al., 2012a; Holding and Allen, 2015b; Cardenas et al., 2015]. Figure 1c shows that topographic depressions commonly exist along coastlines. Figure 1d shows seawater accumulation in a topographic depression one month after the 2004 Indian Ocean tsunami. In addition to retaining water in depressions, mesotopographic features affect the dynamics of the inundation process [Mcleod et al., 2010]. Mesotopography, in particular the connectedness of low-elevation features to the coastline, can affect the timing [Illangasekare et al., 2006] and spatial patterns [Bilskie et al., 2014; Dietrich et al., 2010] of inundation, which further determine the amount and location of infiltration and the subsurface salinization and flushing processes.

This study investigates the effect of mesotopography on groundwater salinization due to ocean surge inundation. To this aim, we set up a 3D numerical model of coupled surface and subsurface flow and salt transport due to ocean surge (section 2), and investigate groundwater salinization (section 3). Specifically, we explore synthetic features of mesotopography, overland flow connectivity, depression storage, and terrain anisotropy to understand their general controls. These features are synthesized on real-world topography. The results have implications for understanding topographic impacts on groundwater assessment and coastal resources management (section 4). 


\section{Methods}

\subsection{HydroGeoSphere}

Numerical modeling was performed using HydroGeoSphere, a 3D, finite element, and fully coupled surface-subsurface model. HydroGeoSphere was selected because it is a robust simulator of advective-dispersive-diffusive salt transport for a coupled surface and subsurface system under variably saturated conditions [Therrien et al., 2006], and it has been demonstrated

to be suitable for simulating overwash salinization [Yang et al., 2013, 2015a; Holding and Allen, 2015a; Holding and Allen, 2015b]. In HydroGeoSphere, the transient 3D variably saturated subsurface flow is calculated by Richards equation and Darcy's law. The 2D surface flow is represented with the diffusion-wave approximation of the Saint Venant equation [Therrien et al., 2006]. The advection-dispersion-diffusion equation for salt transport is solved in both variably saturated subsurface and surface domains. The model uses a dual-node approach to numerically couple subsurface and surface domains. This approach assumes that the surface and subsurface domains are separated by a thin porous layer whose thickness is the coupling length. The exchange flux between the two domains is explicitly calculated. Details concerning the theory, governing equations, and numerical solution techniques of HydroGeoSphere are given in Therrien et al. [2006].

\subsection{Simulation Technique, Boundary Conditions, and Model Parameters}

The model domain was selected to represent a 3D unconfined aquifer extending offshore with a surface water domain along the top. The domain was $4 \mathrm{~km}$ long and $2.5 \mathrm{~km}$ wide with a bottom layer $30 \mathrm{~m}$ below the normal sea level (Figure 2). In the base case, we used a simple slope of $0.03 \%$ (average slope along the coast of Delaware, USA) to represent the macrotopographic feature of the landward domain. In other simulation scenarios, we added mesotopographic 
features based on synthetic surfaces and real-world digital elevation maps. The model domain was laterally discretized at a $50 \mathrm{~m}$ resolution in each direction, with 10 vertical layers with decreasing thickness from the base to the ground surface. We used $0.5 \mathrm{~m}$ resolution near the ground surface where the main hydraulic head and salt transport dynamics occur, and 10 near the bottom of the domain, resulting in a grid of 41310 nodes and $360003 \mathrm{D}$ elements. The $50 \mathrm{~m}$ grid resolution does not permit simulation of fine-scale salt transport, though density fingering does still develop in the simulations. In order to determine whether a higher discretization could affect simulation results, we established simulations with increased discretization ( $\sim \mathrm{x}$ the base case) for the base case simulation scenario. The higher resolution caused negligible differences in volume of unsaturated zone, overland salt storage and subsurface salt storage (Figure S1), which indicated that the initial resolution was appropriate to capture the overall infiltration and subsurface salt transport processes.

The boundary conditions applied for fluid flow and salt transport are shown in Figure 2. In the subsurface domain, a constant annual net precipitation rate $(300 \mathrm{~mm} /$ year) was specified along the landward top boundary $(x \geq 500 \mathrm{~m})$. We did not consider transient recharge conditions because over the long term, daily and seasonal changes would not significantly affect long-term recovery time. The two shore-perpendicular model boundaries and the aquifer bottom were assigned no-flow. An initial steady-state simulation was run with a $2 \mathrm{~m}$ head along the landward boundary and mean sea level along the seawater boundary. The simulated freshwater flux from that simulation was assigned to the landward boundary, along with a salt concentration of $0 \mathrm{~g} \mathrm{~L}^{-1}$. This boundary condition allowed for an increase in head along that boundary due to the ocean surge. The seaside boundary was assigned a time-variable head $h_{\text {sea }}$. We chose the theoretical

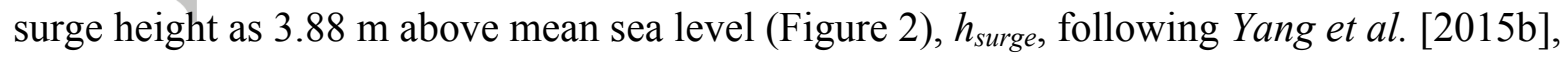


corresponding to a surge of combined wave set-up and sea-level rise for a 100-year return period according to Chini et al. [2012]. The head at computational element $e$ along the vertical seaward boundary, $\left.h_{\text {sea }}(t)\right|_{e}$, is calculated as:

$\left.h_{\text {sea }}(t)\right|_{e=1,2, \ldots, n}=\left(h_{\text {surge }}(t)-\left.z\right|_{e=1,2, \ldots, n}\right) \frac{\rho_{s}}{\rho_{0}}+\left.z\right|_{e=1,2, \ldots, n}$

where $\rho_{s}$ is the density of seawater and $\rho_{0}$ is the density of freshwater, $z$ is the elevation of computational element $e$. The concentration along the vertical seaward boundary was assigned constant seawater concentration $\left(35 \mathrm{~g} \mathrm{~L}^{-1}\right)$.

For the surface domain, hydraulic head $h_{\text {surface }}$ was prescribed along coastline cells as the height of the surge $h_{\text {surge. }}$. The salt concentration was constant seawater concentration (i.e., $35 \mathrm{~g} \mathrm{~L}^{-1}$ ). Surface properties (Manning roughness coefficient) were selected from literature to represent typical values for beaches and land (Table 1).

Subsurface model properties typical of a coastal aquifer were selected (Table 1). These parameters were held constant over the set of simulations in order to focus on topographic, rather than subsurface hydrogeological conditions. Hydraulic conductivity of a sandy aquifer was the class-average values in the USDA (U.S. Department of Agriculture) soil texture database [Schaap et al., 2001].

Each simulation was carried out in two stages: (1) an equilibration period $(t=-20000 \mathrm{~d}$ to $t=0$

d) to establish initial conditions and landward boundary flux for the applied topography and constant mean sea level boundary condition (steady state model), and (2) an ocean surge stage ( $t$

$=0 \mathrm{~d}$ to $t=60000 \mathrm{~d}$ ) using the surge height boundary condition (transient model). 


\subsection{Groundwater Salinization Assessment Criteria}

We developed three assessment criteria: seawater infiltration, salinized volume, and flushing time, to describe the groundwater salinization process (Figure 3). Two criteria related to seawater infiltration are calculated: the cumulative volume of water that has infiltrated from the surface into the subsurface across the landward domain $(x \geq 500 \mathrm{~m})$, and the rate of infiltration over time. Salinized volume is the volume of the aquifer within which salt concentration is $\geq 0.5$

$\mathrm{g} \mathrm{L}^{-1}$, the U.S. Environmental Protection Agency drinking water standard [EPA, 2009].

Similarly, we calculated the temporal variation in salinized volume and the maximum volume salinized throughout each simulation. Flushing time was calculated for each column of the model grid. In any given column, the salt concentration of each of the 10 vertical cells is $C_{k, k=1,2, \ldots, 10}$.

The flushing time is calculated as:

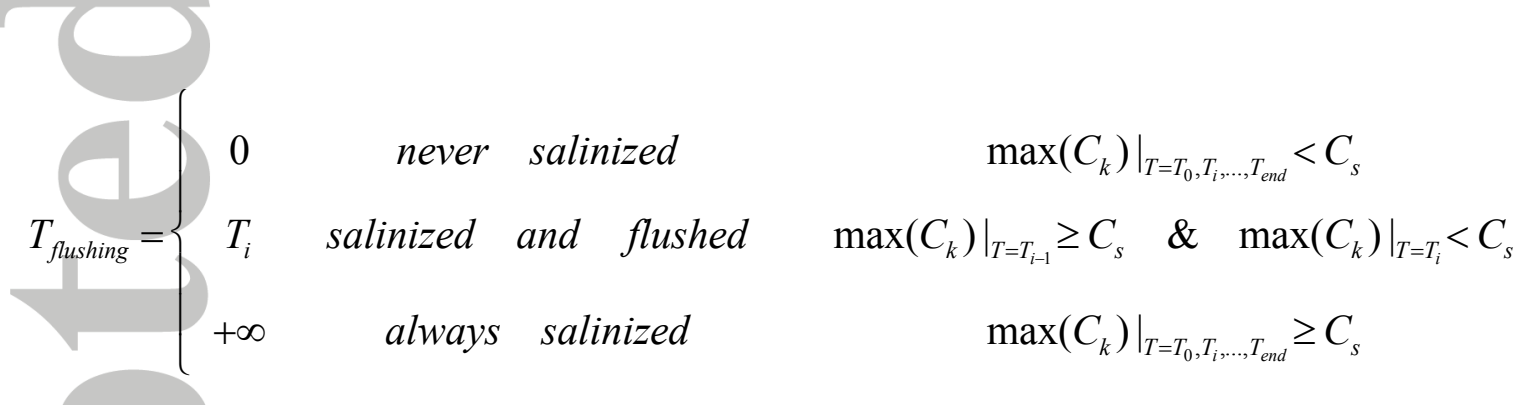

To compare the flushing between different cases, the flushing time distribution was calculated by excluding the regions that are either always or never salinized. The 25 th, 50 th, 75 th, and 100 th percentiles of the distribution were then compared. We note that this is a metric for comparative analysis of the various topographic cases considered in this work. In real systems, many other factors, including subsurface heterogeneity, would affect flushing time, so the values should be interpreted with caution. 


\subsection{Coastal Topography}

We generated four different types of raster Digital Elevation Models on a rectangular domain

(51x 71 elements) to represent synthetic topography $2.5 \mathrm{~km}$ wide and $3.5 \mathrm{~km}$ long (Figure 4).

Following Thompson et al. [2010], we used 2D sinusoidal waves with random translation, as a

parsimonious and tractable representation of coastal topography. To increase the range of structural complexity, we followed the work of Zinn and Harvey [2003] and Antoine et al.

[2009] to generate three other types of topography with contrasting structural connectivity properties. These types were multigaussian random fields transformed so that high, middle, or

low elevation values are connected. The resulting four types of topographic fields were: (1)

Crater: connected crests with isolated depressions, (2) Random: standard multi-Gaussian fields

with connected median values and isolated crests and depressions, (3) River: connected

depressions with isolated crests, and (4) Sine: 2D sinusoidal waves with fixed amplitude and

fixed wavelength. The River and Crater types represented two extremes of drainage channels and dunes in the coast. All of fields had a $0-\mathrm{m}$ mean height and a $0.5-\mathrm{m}$ standard deviation, as well as near-identical isotropic spatial covariance functions. To represent macrotopography, the elevation data were superimposed on the $0.03 \%$ topographic gradient (Figure $4 \mathrm{e}-\mathrm{h}$ ).

To explore the role of topographic depressions, we generated normal, depression-removed, and depression-doubled topographic cases. First, the four simulated normal topographic types $\left(T_{n}\right)$ (i.e., Crater, Random, River, and Sine from previous step) were transformed to create cases with depression-removed cases $\left(T_{d r}\right.$; Figure $\left.4 \mathrm{a}-\mathrm{d}\right)$ using the "Fill" tool in ARCMAP 10.0

[Environmental systems research institute, 2011] geographic information system (GIS) software.

Depression-doubled topography $\left(T_{d d}\right)$ was generated as (Figure 4i-1):

$T_{d d}=T_{d r}-2 \times\left(T_{d r}-T_{n}\right)$ 
Geomorphic features tend to display directional anisotropy relative to the coastline: streams and tidal channels tend to be shore-perpendicular, and dunes are shore-parallel. We applied anisotropic spatial covariance functions on the most-contrasting Crater- and River-type fields to introduce shore-perpendicular and shore-parallel characteristics (Figure 4m-p).

Including both isotropic and anisotropic topographies, there were 16 representations of synthetic topography (Figure 4). Five statistically equivalent realizations were generated for each. Crater-, Random-, and River-type realizations were generated by varying the random seeds in the statistical simulation, whereas the Sine-type realizations were generated by varying the phase in relation to the boundaries. Because the sine topographies do not have random parameters, but the point on the boundary at which the sine wave begins can be phase-shifted (ie, elevation doesn't have to start at 0 on the boundary).

Simulations with real-world topography were conducted for comparison with synthetic topography. A part of the Delaware coastal topography (Figure S2) was divided into 9 pieces. The original topography was a digital elevation model (DEM) with a resolution of 50-m and dimension of 51 by 71 . This is referred to as Real topography. In order to remove macrotopographic effects, the topographic trend, or slope, was removed and topography was standardized to $0 \mathrm{~m}$ mean and $0.5 \mathrm{~m}$ standard deviation to match the synthetic fields, then the $0.03 \%$ slope was added. Therefore, the 9 cases of Real topography were transformed into 9 cases of new topographic fields, which are referred to as Normalized Real topography. The transformed Normalized Real topographic fields enable comparison of the meso-topographic features only. 


\subsection{Topographic Indicators}

Depression storage can be used as an indicator because it affects the retention capacity of overland flow. Depression storage (or surface storage) is widely used in the understanding of topographic control on overland flow and infiltration processes [Antoine et al., 2009; Frei et al., 2010; Le and Kumar, 2014]. The depression storage was calculated for each field to identify the salinization indication capability.

Overland flow connectivity can be used as another indicator because it controls the movement of seawater on top of the aquifer. Many connectivity indicators have been developed in hydrology, geomorphology, and ecology [e.g., Antoine et al., 2009; Larsen et al., 2012; Peñuela et al., 2013; Lexartza-Artza and Wainwright, 2009]. Here, we tested three connectivity indicators (i.e., CFIS: connectivity function integral scale, percolation probability, and Euler number) from [Antoine et al., 2009]. The ability of these connectivity indicators to discriminate among the mesotopography types used in this study was weak (Figure S3). Because the scale is greater in our study than the microtopographic study by Antoine et al. [2009], the boundary effect degrades the discriminative capacity.

We propose new indicators of topographic connectivity as they relate to overland flow due to ocean surges. The new pair of connectivity indicators is "climbing and resting steps", which describes runup inundation processes based on energy dissipation. On a given DEM connecting sea to land, the land surface is assumed impermeable, and the flood flows landward with infinite velocity. The water level of the flood is raised step by step so that only one cell of the DEM is inundated in one step. The process is called a flood fill algorithm [Morton, 2012; Soille et al., 2003]. Figure 5a presents the flood fill process on one example of River type topography. Each step corresponding to an increase in water level in the flood fill algorithm can be classified into 
two categories: climbing and resting. The climbing step $\left(s_{c}\right)$ overcomes gravity, which dissipates a large amount of energy. The resting step $\left(s_{r}\right)$ may or may not fill depressions, and the flow moves laterally without dissipating energy (Figure 5b). Energy loss against gravitational force for the whole runup process is determined by $h_{\text {surge }}$. For a given $h_{\text {surge }}(\mathrm{e} . \mathrm{g} ., 3.88 \mathrm{~m}$ in the theoretical surge), greater $s_{c}$ means less energy is dissipated for each step, which suggests the runup will be able to penetrate more steps landward (i.e., greater inundation area). The means as well as $1^{\text {st }}$ and $9^{\text {th }}$ deciles of the climbing and resting steps connectivity indicators clearly distinguish all mesotopography types (Figure 5c and 5d). The Sine type had an order of magnitude higher resting steps than the others (Figure 5c), whereas all four synthetic types had a similar order of magnitude of climbing steps (Figure 5d). The resting steps (Figure 5e) of Normalized Real topography had a similar order of magnitude as Crater, Random, and River types. The climbing steps of Normalized Real topography had a similar order of magnitude as River and Random (Figure 5f). Comparing between the two indicators, we found that climbing steps are two orders of magnitude higher than resting step. In the case of our topographies, climbing steps dissipate significantly more energy than resting steps. Therefore, we chose climbing steps as the connectivity indicator. Resting steps may be an effective indicator in systems in which climbing steps are too close to discriminate each other (e.g. flooding on flat surface).

\section{Results}

\subsection{Simulation Results for Base-Case Topography}

The simulated salinization process in the base-case topography (simple slope land surface, Figure 6a) provides insights into the coupling between the surface and subsurface during an 
ocean surge (Figure 6). The cumulative volume of infiltrated seawater was $2.8 \times 10^{6} \mathrm{~m}^{3}$. The maximum salinized volume was $1.6 \times 10^{8} \mathrm{~m}^{3}$, which was reached 6.9 years after the ocean surge (Figure 6b). The location where flushing time was greatest (i.e., 53.5 years) was $\mathrm{x}=2650 \mathrm{~m}$, which is close to the inundation line (i.e., $\mathrm{x}=2900 \mathrm{~m}$ ) (Figure 6c). The flushing time decreased gradually from its maximum zone toward the coastline until it reached the always-salinized zone (Figure 6c). The distribution of flushing times for all model locations showed two peaks, one at 5-10 years, and another at $35-40$ years. The $25^{\text {th }}$ percentile of flushing time was 15 years, which mainly occurred near the coast (i.e. $1000 \mathrm{~m}<\mathrm{x}<1500 \mathrm{~m}$ ). The $50^{\text {th }}$ percentile of flushing time was close to 40 years. The inland region $(2000 \mathrm{~m}<\mathrm{x}<2900 \mathrm{~m})$ contributed flushing times greater than 40 years (Figure 6d).

\subsection{Simulation Results for Synthetic Topography}

Simulations show that depression storage has a substantial impact on the amount of seawater that infiltrates across the ground surface (Figure 7a), but little impact on the volume of aquifer that is salinized (Figure 7b). Infiltrated seawater in the depression-doubled cases ranged from $2.9 \times 10^{6}$ to $4.4 \times 10^{6} \mathrm{~m}^{3}$, equivalent to 0.33 to $0.50 \mathrm{~m}$ depth of water over the area of $3500 \mathrm{~m}$ by $2500 \mathrm{~m}$, which is $4 \%$ to $56 \%$ greater than that of the base case (i.e., $2.8 \times 10^{6} \mathrm{~m}^{3}$ ). The maximum infiltrated seawater was obtained in the Crater type, which had the greatest value of depression storage. The relationship between depression storage and the volume of infiltrated seawater is approximately linear $\left(R^{2}=0.79, p\right.$-value $\left.<0.001\right)$. This relationship breaks down at higher magnitudes of depression storage because trapping of seawater in large depressions can limit the spatial extent of the inundation, which has a negative effect on the amount of infiltration.

The topographic type (i.e., Crater, Random, River, Sine) had little impact on infiltrated amount of seawater (Figures 7c), but it had a significant effect on the volume of aquifer that was 
salinized (Figure 7d). The average amount of infiltrated seawater for all the synthetic types was greater than that of the base case (Figure 7c). The Crater and Sine types had similar ranges of infiltrated seawater, while the range decreased in Random type and River type. The average values of the maximum salinized volume were in the order: Crater $<$ Random $<$ Sine $<$ River (Figure 7d).

The climbing steps connectivity indicator was a good quantitative predictor of maximum salinized volume (Figure 7f), but not of the volume of infiltrated seawater (Figure 7e). The scatterplot of maximum salinized volume and climbing steps (Figure 7f) shows two clusters:

Sine type with high resting steps, and Crater, Random, and River types, with positive correlations. A linear regression $\left(R^{2}=0.58, p\right.$-value $\left.<0.001\right)$ was obtained without the cases of Sine topography.

The flushing time distributions demonstrated longer tails when depression storage increased in all the types (Figure 8). As depression storage increased from zero (i.e. depression-removed) to normal and, the maximum flushing time increased by $10-15$ years, whereas there was little increase in the median, which suggests that depressions contributed to the locations with extremely long flushing time. Further increase of depression storage from normal to double did not cause significant change on the flushing time distribution. All types had similar distributions with two peaks: the first at $\sim 5-10$ years and the second at $\sim 50$ years. Compared to the base case (Figure 6d), which has a maximum flushing of 53.5 years, mesotopographic variations increased the maximum flushing time by $30-45$ years.

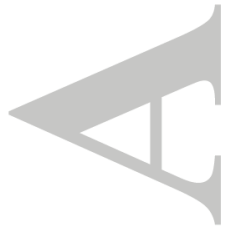




\subsection{Simulation Results for Real and Normalized Real Topography}

Simulation of Real and Normalized Real topography demonstrated different ranges in maximum salinized aquifer volume and the amount of infiltrated seawater. The volume of infiltrated seawater ranged from $1.7 \times 10^{6}$ to $26.7 \times 10^{6} \mathrm{~m}^{3}$ in the 9 cases of Real topography, while the range was significantly less in Normalized Real topography cases, $2.6 \times 10^{6}$ to $3.9 \times 10^{6} \mathrm{~m}^{3}$ (Figure 9). The maximum salinized volume ranged from $0.5 \times 10^{8}$ to $1.2 \times 10^{8} \mathrm{~m}^{3}$ in the Real topography cases. In the Normalized Real topography cases, the maximum salinized volume was greater, ranging from $1.1 \times 10^{8}$ to $1.7 \times 10^{8} \mathrm{~m}^{3}$. This was because the overall slope of the Real topography was $0.038 \%$ on average, slightly steeper than the Normalized Real topography $(0.03 \%)$, which impeded the runup process. Comparing the ranges between Real and Normalized Real topography, we can conclude that macrotopography has a greater impact on the infiltrated seawater than the maximum salinized volume.

The indication capability of climbing steps for Normalized Real topography was better than that of depression storage. The linear trend between depression storage and infiltrated seawater did not show up in Normalized Real cases due to small depression storage of the real-world topography we selected (Figure 10a). In addition, the depression storage does not include spatial information. Usually, depressions in real-world topography are not evenly distributed across the surface. A larger number of inland depressions will not increase the infiltrated seawater, because inundation cannot reach them. In contrast, the scatterplot of maximum salinized volume and climbing steps were consistent with the relation obtained in synthetic cases (Figure 10b).

Each of the 9 cases with Normalized Real topography had different simulated flushing time distributions (Figure 11). The $25^{\text {th }}$ percentiles ranged from 14.0 to 33.3 years, $50^{\text {th }}$ percentiles ranged from 31.4 to 41.5 years, and $75^{\text {th }}$ percentiles ranged from 38.8 to 49.5 years. The greatest 
flushing time occurred in Case 4, which retained a large volume of ponded seawater in a salt march depression. The shortest flushing times, 60 years, occurred in Cases 8 and 9, which had relatively flat topography and high, continuous dunes.

\subsection{Comparison Between Synthetic and Normalized Real Topography}

The ranges of the infiltrated seawater amount for synthetic cases increased to cover the ranges of Normalized Real topography by adding depression-removed and depression-doubled cases. This was because Normalized Real cases had a greater range in depression storage than the normal synthetic cases (Figure 4e-h). Inclusion of the depression-removed and depression-doubled cases increases the span infiltrated seawater to a range of $2.2 \times 10^{6}$ to $4.4 \times 10^{6} \mathrm{~m}^{3}$, which is greater than that of Normalized Real topography (Figure 12a).

The ranges of maximum salinized volume for synthetic cases increased to cover the ranges of Normalized Real topography by adding the directional characteristic. When the directional characteristic of River topography varied from shore-perpendicular to isotropy to shore-parallel, the variability of maximum salinized volume increased, whereas the mean value did not change significantly (Figure 12b). The same change in directional characteristic on Crater-type topography resulted in a considerable decrease in the mean of the maximum salinized volume, while the ranges remained similar (Figure 12b).

\section{Discussion}

This study highlights the importance of mesotopographic effects on surge-induced groundwater salinization and fills a gap in spatial scale between macrotopography and microtopography. By

normalizing our synthetic and real-world topography to the same slope and standard deviation in 
elevation, we isolated mesotopographic effects and gained a better understanding of process controls. Our results suggest that coastlines with both few connected low-topography features aligned perpendicular to the shoreline and few topographic depressions (Figure 4a) are least vulnerable to groundwater salinization, assuming all other factors, such as macrotopographic gradient and subsurface features, are equal. Thus, vulnerability assessments and strategies for altering land surface to minimize groundwater salinization may focus on these topographic features.

\subsection{Implications for Coastal Resource Management}

The modeling results reveal the role of different landscape features on overwash groundwater salinization processes. Both the extent of inundation, or surge runup, and the rate of recession, or surge rundown, are important factors affecting aquifer salinization. Topographic features that impede landward movement of floodwater, such as the connected high-elevation features of dunes (i.e., Crater-type), tend to reduce inundation extent and, as a result, reduce the volume of the aquifer that is salinized. However, because these features impede drainage back to the sea and form topographic depressions that trap surface water, they tend to increase the volume of seawater that infiltrates the aquifer as well as the maximum flushing times, in contrast to connected low-elevation topographic features (i.e., River-type) that allow widespread inundation but also quick drainage of the land surface [Ramsey et al., 2011]. The results suggest that topography is a primary control on both the amount and spatial extent of seawater infiltration.

Consideration of directional characteristics leads to improved understanding of overland flow connectivity and resulting impacts on aquifer salinization. The directional orientation of topographic features strongly influences the spatial and temporal dynamics of the surge runup and rundown process. Crater-type topographies have many dune-like features, which can impede 
the runup of floodwater and reduce inundation distance, particularly if they are oriented in a shore-parallel direction. This obstructing effect is much less when the orientation is shoreperpendicular, allowing for greater spatial extent of flooding. Such spatial extent affects the mean value of maximum salinized volume in Crater type (Figure 12b). The function of Rivertype features (i.e., drainage networks) is to convey floodwater, so that the speed of both runup and rundown is increased. The conveying effect of drainage networks is maximized when drainage conduits are perpendicular to shore (i.e., parallel to the flood motion direction). The timing of the flooding did not significantly affect the mean value of maximum salinized volume (Figure 12b). The shore-parallel case of River type had least conveying effect. Therefore, some channels may not be inundated if they happened to further than the inundation line. Such impacts introduced a greater range of salinized volume in the shore-parallel cases of River-type topography (Figure 12b). As the conveying effect increased in isotropy and shore-perpendicular cases, the impact of River-type topography was reduced, therefore less ranges in maximum salinized volume were obtained (Figure 12b). By considering such directional characteristics, we isolated the spatial effects of Crater-type features and the temporal effects of River-type features during runup and rundown processes. These insights may be valuable in coastal environmental protection and land conservation [Larsen et al., 2012] for identifying different vulnerability types.

Understanding the role of mesotopographic depressions is valuable for coastal wetland assessment. These depressions often host geographically isolated wetlands, with various ecological benefits [Tiner, 2003]. However, in coastal areas, ecosystems in these depressions can be severely degraded by ocean surge inundation [Ross et al., 2008]. The long-term impact is that increasing salinity in groundwater-dependent ecosystems selectively kills salt-sensitive 
vegetation [Ross et al., 2008]. For example, Hauser et al. [2015] found that severe degradation occurred in $41 \%$ of New Jersey coastal wetlands due to Hurricane Sandy, and that $51 \%$ of the degradation was long-term. Our modeling results suggest that surface depressions lead to increased saltwater infiltration and longer flushing times - that floodwater retention in wetlands affects both surface and subsurface water quality. Therefore, coastal land management (e.g., impoundments [Ramsey et al., 2011] and aquaculture [Shameem et al., 2014; Shameem et al., 2015]) should be integrated with groundwater salinization assessments [Day et al., 2007] to determine overall impacts and risks of ocean surges to coastal systems.

Removing ponded saltwater after a surge event is an effective remedial action to reduce the damage of groundwater salinization. Comparing cases with and without depressions indicates that ponded seawater contributes to a considerable amount of total infiltrated seawater and leads to a significant increase in flushing time. Chui and Terry [2012] recommended that saline damage can be mitigated by pumping ponded seawater out of the depression back to the ocean soon after storms abate. Holding and Allen [2015a] modeled the timing and duration of remedial action, and found that it is critical to pump the ponded seawater as soon as possible following a storm surge overwash. Ramsey et al. [2011] found that the drainage ability of impounded marshes is a major control on the rundown rate after surge inundation.

\subsection{Implications for Understanding Coastal Processes}

One important implication of the salinization modeled is associated with vulnerability of fresh groundwater resources to sea-level rise. It has been found that long-term sea-level rise may or may not introduce significant lateral seawater intrusion, depending on whether hydraulic heads on land maintain a balance with rising sea levels [Werner and Simmons, 2009; Michael et al., 2013; Holding and Allen, 2015a]. Regarding to the vertical salinization, the displacement of the 
coastal topography as shoreline retreat will cause different groundwater salinization processes due to ocean surges.

The insights gained from this analysis have implications for understanding impacts of ocean surge inundation on subsurface biogeochemical cycles [e.g., Sawyer et al., 2016]. We show that topography is a primary control on the spatial extent of salinization, the amount and timeframe over which infiltration occurs, and the process of flushing through the subsurface. All of these factors likely affect the spatial and temporal dynamics of disturbance in salinity, $\mathrm{pH}$, and redox of the near surface. Such disturbance affects contaminant mobilization [Pardue et al., 2005; Personna et al., 2014; Wong et al., 2015], redox reactions [Frei and Fleckenstein, 2014], and nutrient cycling [Chambers et al., 2013], and could potentially cause health and environmental threats along highly populated coastlines.

\subsection{Limitations}

This study provides a comparison across mesotopography types, which allows for general understanding of their effects on groundwater salinization processes due to overwash. Sensitivity to other important factors, such as precipitation [Holding and Allen, 2015a], vadose zone flow [Holding and Allen, 2015b; Masterson et al., 2014] and hydrogeological properties [Holding and Allen,2015b; Vithanage et al., 2012b], tidal parameters [Yang et al., 2013; Passeri et al., 2015], and surge characteristics were not investigated in this study. We also did not consider impacts of subsurface heterogenenity, which would certainly affect both salinization and flushing processes. Because of this, flushing time should be interpreted with caution, as low-permeability zones would very likely increase flushing times because of mass transfer into slow-flow domains. Additional work would be necessary to more fully assess the impacts of all of these factors on vulnerability to surge-induced salinization. 
Geomorphic dynamics are not considered in this study because the focus is on the long-term impacts on groundwater resources. However, ocean surges are a major agent of geomorphic changes in coastal zones [Cahoon, 2006], and they can modify mesoscale topographic features by up-drift erosion and down-drift deposition [Bilskie et al., 2014; Plant et al., 2010; Nabi et al., 2015]. There may be feedbacks between the surface water dynamics and topography that could impact groundwater salinization. Therefore, coastal management may need to include vulnerability assessment based on current topography but also how the topography may be altered by a surge, and the resulting effect of that on subsurface salinity.

Another overlooked issue is the impact of groundwater pumping, which exacerbates saltwater intrusion [Werner et al., 2013; Ferguson and Gleeson, 2012; Yu et al., 2010]. Generally, pumping may be combined with the changes in rainfall and evapotranspiration to obtain a relative rate of recharge. More details should be considered for optimal management of groundwater, such as, pumping operation, well placement, etc. [Werner et al., 2013]. In addition, at the early stage of salinization, pumping of fresh groundwater after the ocean surge may accelerate the vertical penetration of the infiltrated saltwater from the surface.

\section{Conclusion}

The impact of mesoscale topography on processes of groundwater salinization due to ocean surges was analyzed. A series of 3D variable-density flow and solute transport simulations on both synthetic and real-world topography established that the amount of water that can be stored in surface depressions and connectivity of overland flow are primary controlling factors on overwash groundwater salinization and flushing. Surface depressions that trap and store water increase the amount of seawater that infiltrates into the aquifer, leading to longer tails on flushing 
time distributions. Overland flow connectivity has little effect on the amount of infiltration, but instead controls the extent of surface inundation and the volume of aquifer salinized. Overall, coastlines with greater shore-perpendicular low-elevation connectivity and large volumes of surface depression will be more vulnerable to salinization, with greater aquifer volumes affected, infiltrated salt mass, and longer flushing times. We developed an indicator based on energy dissipation ("climbing steps") that correlates with the volume of aquifer salinized for both synthetic and Normalized Real topography, with potential for use in initial vulnerability assessments. In addition, the spatial and temporal dynamics of inundation are affected by the directional characteristics of landscape features. Compared to an equivalent "simple slope" (base case), the mesotopographic features considered (synthetic and Normalized Real) change the maximum volume of aquifer salinized by $7.5 \%-34 \%$ and increase the amount infiltrated seawater by as much as $56 \%$.

This study represents an initial step in using coupled surface-subsurface models to explore the effect of topography on groundwater salinization caused by ocean surges. Characteristics of landscape features are one of the primary indicators of vulnerability of coastal groundwater systems to sea-level rise. They should be considered when assessing groundwater vulnerability for adaptation, management, and planning purposes because topography determines the temporal and spatial dynamics of infiltrated seawater, which is the initial control on subsurface salinization process. Further work would be needed to fully assess potential vulnerability due to subsurface properties (e.g. soil properties, geological heterogeneity, and pumping rates).

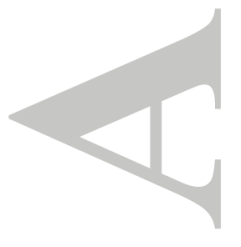




\section{Acknowledgments}

All data for this paper are cited in the reference list and Supporting Information; any additional details can be obtained from the firstauthor(xuan@udel.edu) and corresponding author (hmichael@udel.edu).The authorsare grateful to the three reviewers, the Editor, and the Associate Editor for their insightful comments and suggestions. This work was supported by the National Science Foundation (NSF) EPSCoR Grant No. IIA-1301765 and NSF Grant No. 1151733. We are very grateful for the connectivity calculation code and comments from Dr. Michael Antoine of Université Catholique de Louvain.

\section{References}

Anderson Jr, W. P. (2002), Aquifer salinization from storm overwash, J. Coast. Res., 413-420.

Antoine, M., M. Javaux, and C. Bielders (2009), What indicators can capture runoff-relevant connectivity properties of the micro-topography at the plot scale?, Adv. Water Resour., 32(8), 1297-1310.

Ataie-Ashtiani, B., A. D. Werner, C. T. Simmons, L. K. Morgan, and C. Lu (2013), How important is the impact of land-surface inundation on seawater intrusion caused by sealevel rise?, Hydrogeol. J., 21(7), 1673-1677.

Bailey, R. T. (2015), Quantifying transient post-overwash aquifer recovery for atoll islands in the Western Pacific, Hydrol. Process, 29(20), 4470-4482.

Bilskie, M. V., S. C. Hagen, S. C. Medeiros, and D. L. Passeri (2014), Dynamics of sea level rise and coastal flooding on a changing landscape, Geophys. Res. Lett., 41(3), 927-934.

Cahoon, D. R. (2006), A review of major storm impacts on coastal wetland elevations, Estuaries Coasts, 29(6), 889-898.

Cardenas, M. B., P. C. Bennett, P. B. Zamora, K. M. Befus, R. S. Rodolfo, H. B. Cabria, and M. R. Lapus (2015), Devastation of aquifers from tsunami - like storm surge by Supertyphoon Haiyan, Geophys. Res. Lett., 42(8), 2844-2851.

Chambers, L. G., and T. Z. Osborne (2013), Effect of salinity-altering pulsing events on soil organic carbon loss along an intertidal wetland gradient: a laboratory experiment, Biogeochemistry, 115, 363-383.

Chini, N., Stansby, P.K (2013), Extreme values of coastal wave overtopping accounting for climate change and sea level rise. Coast. Eng. 65, 27-37.

Chui, T. F. M., and J. P. Terry (2012), Modeling Fresh Water Lens Damage and Recovery on Atolls After Storm - Wave Washover, Groundwater, 50(3), 412-420. 
Chui, T. F. M., and J. P. Terry (2013), Influence of sea-level rise on freshwater lenses of different atoll island sizes and lens resilience to storm-induced salinization, J. Hydrol., $502,18-26$.

Church, J.A., P.U. Clark, A. Cazenave, J.M. Gregory, S. Jevrejeva, A. Levermann, M.A. Merri eld, G.A. Milne, R.S. Nerem, P.D. Nunn, A.J. Payne, W.T. Pfeffer, D. Stammer and A.S. Unnikrishnan (2013), Sea Level Change. In: Climate Change 2013: The Physical Science Basis. Contribution of Working Group I to the Fifth Assessment Report of the Intergovernmental Panel on Climate Change [Stocker, T.F., D. Qin, G.-K. Plattner, M. Tignor, S.K. Allen, J. Boschung, A. Nauels, Y. Xia, V. Bex and P.M. Midgley (eds.)]. Cambridge University Press, Cambridge, United Kingdom and New York, NY, USA.

Day, J. W., D. F. Boesch, E. J. Clairain, G. P. Kemp, S. B. Laska, W. J. Mitsch, K. Orth, H. Mashriqui, D. J. Reed, and L. Shabman (2007), Restoration of the Mississippi Delta: lessons from hurricanes Katrina and Rita, science, 315(5819), 1679-1684.

Delsman, J. R., K. R. M. Hu-a-ng, P. C. Vos, P. G. De Louw, G. H. Oude Essink, P. J. Stuyfzand, and M. F. Bierkens (2014), Paleo-modeling of coastal saltwater intrusion during the Holocene: an application to the Netherlands, Hydrol. Earth Syst. Sci., 18(10), 3891-3905.

Dietrich, J. C., S. Bunya, J. J. Westerink, B. A. Ebersole, J. M. Smith, J. H. Atkinson, R. Jensen, D. T. Resio, R. A. Luettich, and C. Dawson (2010), A high-resolution coupled riverine flow, tide, wind, wind wave, and storm surge model for southern Louisiana and Mississippi. Part II: Synoptic description and analysis of Hurricanes Katrina and Rita, Mon. Weather Rev., 138(2), 378-404.

Environmental systems research institute (2011), ArcGIS Desktop, Release 10.0, Redlands, California.

EPA, U. (2009), National primary drinking water regulations, Total Coliforms Fecal Coliforms E Coli, 54 .

Ferguson, G., and T. Gleeson (2012), Vulnerability of coastal aquifers to groundwater use and climate change, Nat. Clim. Change, 2(5), 342-345.

Frei, S., and J. H. Fleckenstein (2014), Representing effects of micro-topography on runoff generation and sub-surface flow patterns by using superficial rill/depression storage height variations, Environ. Model. Softw., 52, 5-18.

Frei, S., G. Lischeid, and J. H. Fleckenstein (2010), Effects of micro-topography on surfacesubsurface exchange and runoff generation in a virtual riparian wetland - A modeling study, Adv. Water Resour., 33(11), 1388-1401.

Gelhar, L.W., C. Welty, and K.R. Rehfeldt (1992), A critical review of data on field-scale dispersion in aquifers, Water Resources Research, 28(7), 1955-1974. 
Hauser, S., M. Meixler, and M. Laba (2015), Quantification of Impacts and Ecosystem Services Loss in New Jersey Coastal Wetlands Due to Hurricane Sandy Storm Surge, Wetlands, $35,1137-1148$.

Holding, S., and D. M. Allen (2015a), From days to decades: numerical modelling of freshwater lens response to climate change stressors on small low-lying islands, Hydrol. Earth Syst. Sci., 19(2), 933-949.

Holding, S., and D. M. Allen (2015b), Wave overwash impact on small islands: Generalised observations of freshwater lens response and recovery for multiple hydrogeological settings, J. Hydrol. 529, 1324-1335

Illangasekare, T. et al. (2006), Impacts of the 2004 tsunami on groundwater resources in Sri Lanka, Water Resour. Res., 42(5), W05201, doi:10.1029/2006WR004876.

Ketabchi, H., D. Mahmoodzadeh, B. Ataie - Ashtiani, and C. T. Simmons (2016), Sea-level rise impacts on seawater intrusion in coastal aquifers: Review and integration, Journal of Hydrol. 535, 235-255.

Larsen, L. G., J. Choi, M. K. Nungesser, and J. W. Harvey (2012), Directional connectivity in hydrology and ecology, Ecol. Appl., 22(8), 2204-2220.

Le, P. V., and P. Kumar (2014), Power law scaling of topographic depressions and their hydrologic connectivity, Geophys. Res. Lett., 41(5), 1553-1559.

Leorri, E., R. Mulligan, D. Mallinson, and A. Cearretta (2011), Sea-level rise and local tidal range changes in coastal embayments: An added complexity in developing reliable sealevel index points, J. Integrated Coastal Zone Manage., 11(3), 307-314.

Lexartza-Artza, I., and J. Wainwright (2009), Hydrological connectivity: Linking concepts with practical implications, Catena, 79(2), 146-152.

Little, C. M., R. M. Horton, R. E. Kopp, M. Oppenheimer, G. A. Vecchi, and G. Villarini (2015), Joint projections of US East Coast sea level and storm surge, Nat. Clim Change, (5), 1114-1120.

Masterson, J. P., M. N. Fienen, E. R. Thieler, D. B. Gesch, B. T. Gutierrez, and N. G. Plant (2014), Effects of sea - level rise on barrier island groundwater system dynamicsecohydrological implications, Ecohydrology, 7(3), 1064-1071.

McDonnell, J. J. (2013), Are all runoff processes the same?, Hydrol. Process., 27(26), 41034111.

Mcleod, E., B. Poulter, J. Hinkel, E. Reyes, and R. Salm (2010), Sea-level rise impact models and environmental conservation: A review of models and their applications, Ocean Coast. Manag., 53(9), 507-517. 
Michael, H. A., C. J. Russoniello, and L. A. Byron (2013), Global assessment of vulnerability to sea - level rise in topography - limited and recharge - limited coastal groundwater systems, Water Resour. Res., 49(4), 2228-2240.

Morgan, L. K., M. Bakker, and A. D. Werner (2015), Occurrence of seawater intrusion overshoot, Water Resour. Res., 51(4), 1989-1999.

Morton, C. (2012), Python flood-fill algorithm, http://arcgisandpython.blogspot.com/2012/01/python-flood-fill-algorithm.html, (Accessed 5 May 2015).

Nabi, M., I. Kimura, S. M. Hsu, S. Giri, and Y. Shimizu (2015), Computational modeling of dissipation and regeneration of fluvial sand dunes under variable discharges, J. Geophys. Res. Earth Surf, 120(7), 1390-1403.

Nicholls, R. J., and A. Cazenave (2010), Sea-level rise and its impact on coastal zones, science, 328(5985), 1517-1520.

Pardue, J. H., W. M. Moe, D. McInnis, L. J. Thibodeaux, K. T. Valsaraj, E. Maciasz, I. Van Heerden, N. Korevec, and Q. Z. Yuan (2005), Chemical and microbiological parameters in New Orleans floodwater following Hurricane Katrina, Environ. Sci. Technol., 39(22), 8591-8599.

Passeri, D. L., S. C. Hagen, S. C. Medeiros, M. V. Bilskie, K. Alizad, and D. Wang (2015), The dynamic effects of sea level rise on low gradient coastal landscapes: a review, Earths Future, 3(6), 159-181.

Peñuela, A., M. Javaux, and C. L. Bielders (2013), Scale effect on overland flow connectivity at the plot scale, Hydrol. Earth Syst. Sci., 17(1), 87-101.

Personna, Y. R., X. Geng, F. Saleh, Z. Shu, N. Jackson, M. P. Weinstein, and M. C. Boufadel (2015), Monitoring changes in salinity and metal concentrations in New Jersey (USA) coastal ecosystems Post-Hurricane Sandy, Environ. Earth Sci., 73(3), 1169-1177.

Plant, N. G., H. F. Stockdon, A. H. Sallenger, M. J. Turco, J. W. East, A. A. Taylor, and W. A. Shaffer (2010), Forecasting hurricane impact on coastal topography, Eos Trans. Am. Geophys. Union, 91(7), 65-66.

Qu, W., H. Li, L. Wan, X. Wang, and X. Jiang (2014), Numerical simulations of steady-state salinity distribution and submarine groundwater discharges in homogeneous anisotropic coastal aquifers, Adv. Water Resour., 74, 318-328.

Rabbani, G., S. H. Rahman, and L. Faulkner (2013), Impacts of climatic hazards on the small wetland ecosystems (ponds): evidence from some selected areas of coastal Bangladesh, Sustainability, 5(4), 1510-1521. 
Ramsey III, E., Z. Lu, Y. Suzuoki, A. Rangoonwala, and D. Werle (2011), Monitoring duration and extent of storm-surge and flooding in Western Coastal Louisiana marshes with Envisat ASAR data, Sel. Top. Appl. Earth Obs. Remote Sens. IEEE J. Of, 4(2), 387-399.

ROSETTA (2005), US Salinity Laboratory : ROSETTA Class Average Hydraulic Parameters, Available from: http://www.ars.usda.gov/Services/docs.htm?docid=8955 (Accessed 5 May 2015)

Ross, M. S., J. J. O'Brien, R. G. Ford, K. Zhang, and A. Morkill (2008), Disturbance and the rising tide: the challenge of biodiversity management on low-island ecosystems, Front. Ecol. Environ., 7(9), 471-478.

Rotzoll, K., and C. H. Fletcher (2013), Assessment of groundwater inundation as a consequence of sea-level rise, Nat. Clim. Change, 3(5), 477-481.

Sawyer, A. H., D. A. Edmonds, and D. Knights (2015), Surface water-groundwater connectivity in deltaic distributary channel networks, Geophys. Res. Lett., 42(23), 10299-10306.

Sawyer, A. H., H. A. Michael, and A. W. Schroth (2016), From soil to sea: the role of groundwater in coastal critical zone processes. WIREs Water, doi:10.1002/wat2.1157.

Schaap, M. G., F. J. Leij, and M. T. van Genuchten (2001), ROSETTA: a computer program for estimating soil hydraulic parameters with hierarchical pedotransfer functions, J. Hydrol., 251(3), 163-176.

Shameem, M., S. Momtaz, and A. Kiem (2015), Local perceptions of and adaptation to climate variability and change: the case of shrimp farming communities in the coastal region of Bangladesh, Clim. Change, 133(2), 253-266.

Shameem, M. I. M., S. Momtaz, and R. Rauscher (2014), Vulnerability of rural livelihoods to multiple stressors: A case study from the southwest coastal region of Bangladesh, Ocean Coast. Manag., 102, 79-87.

Soille, P., J. Vogt, and R. Colombo (2003), Carving and adaptive drainage enforcement of grid digital elevation models, Water Resour. Res., 39(12), 1366.

Taylor, R. G. et al. (2013), Ground water and climate change, Nat. Clim Change, 3(4), 322-329, doi:10.1038/nclimate1744.

Terry, J. P., and A. C. Falkland (2010), Responses of atoll freshwater lenses to storm-surge overwash in the Northern Cook Islands, Hydrogeol. J., 18(3), 749-759.

Therrien, R., R. G. McLaren, E. A. Sudicky, and S. M. Panday (2006), HydroGeoSphere: A three-dimensional numerical model describing fully-integrated subsurface and surface flow and solute transport, Groundwwater Simul Group Waterloo Ont, 349 pp.

Thompson, S. E., G. G. Katul, and A. Porporato (2010), Role of microtopography in rainfall runoff partitioning: An analysis using idealized geometry, Water Resour. Res., 46(7). 
Tiner, R. W. (2003), Geographically isolated wetlands of the United States, Wetlands, 23(3), 494-516.

Törnqvist, T. E., and D. J. Meffert (2008), Sustaining coastal urban ecosystems, Nat. Geosci., $1(12), 805-807$.

Vithanage, M., P. Engesgaard, K. G. Villholth, and K. H. Jensen (2012a), The effects of the 2004 tsunami on a coastal aquifer in Sri Lanka, Groundwater, 50(5), 704-714.

Vithanage, M., P. Engesgaard, K. H. Jensen, T. H. Illangasekare, and J. Obeysekera (2012b), Laboratory investigations of the effects of geologic heterogeneity on groundwater salinization and flush-out times from a tsunami-like event, J. Contam. Hydrol., 136-137, $10-24$.

Werner, A. D., M. Bakker, V. E. Post, A. Vandenbohede, C. Lu, B. Ataie-Ashtiani, C. T. Simmons, and D. A. Barry (2013), Seawater intrusion processes, investigation and management: recent advances and future challenges, Adv. Water Resour., 51, 3-26.

Werner, A. D., and C. T. Simmons, (2009), Impact of sea-level rise on seawater intrusion in coastal aquifers. Ground Water, 47:197-204.

Wong, N. L. V., S. G. Johnston, E. D. Burton, P. Hirst, L. A. Sullivan, R. T. Bush, and M. Blackford, (2015), Seawater inundation of coastal floodplain sediments: Short-term changes in surface water and sediment geochemistry, Chemical Geology, 398, 32-45.

Yang, J., T. Graf, M. Herold, and T. Ptak (2013), Modelling the effects of tides and storm surges on coastal aquifers using a coupled surface-subsurface approach, J. Contam. Hydrol., $149,61-75$.

Yang, J., T. Graf, and T. Ptak (2015a), Impact of climate change on freshwater resources in a heterogeneous coastal aquifer of Bremerhaven, Germany: A three-dimensional modeling study, J. Contam. Hydrol., 177, 107-121.

Yang, J., T. Graf, and I. T. Ptak (2015b), Sea level rise and storm surge effects in a coastal heterogeneous aquifer: a 2D modelling study in northern Germany, Grundwasser, 20(1), $39-51$.

Yu, W., C. I. Voss, H. A. Michael, K. M. Ahmed, L. Feinson, M. M. R. Khan, and A. Tuinhof (2010), Implications of climate change for fresh groundwater resources in coastal aquifers in Bangladesh, Wash. DC World Bank.

Zhou, P., G. Li, Y. Lu, and M. Li (2014), Numerical modeling of the effects of beach slope on water-table fluctuation in the unconfined aquifer of Donghai Island, China, Hydrogeol. J., 22(2), 383-396.

Zinn, B., and C. F. Harvey (2003), When good statistical models of aquifer heterogeneity go bad: A comparison of flow, dispersion, and mass transfer in connected and multivariate Gaussian hydraulic conductivity fields, Water Resour. Res., 39(3). 


\section{Tables}

Table 1. HydroGeoSphere model parameter values and attributes

\begin{tabular}{llll}
\hline & & & \\
\hline Description & Value & Unit & Reference \\
\hline Hydraulic conductivity & 6.43 & $\mathrm{~m} \mathrm{day}^{-1}$ & ROSETTA [2005] \\
Saturated water content & 0.375 & $\mathrm{~cm}^{3} \mathrm{~cm}^{-3}$ & ROSETTA [2005] \\
Residual water content & 0.053 & $\mathrm{~cm}^{3} \mathrm{~cm}^{-3}$ & ROSETTA [2005] \\
Inverse of air entry pressure & 3.52 & $\mathrm{~m}^{-1}$ & ROSETTA [2005] \\
Pore-size distribution index & 3.18 & $\mathrm{~N} / \mathrm{A}$ & ROSETTA [2005] \\
$\begin{array}{l}\text { Longitudinal dispersivity } \\
\text { Lateral dispersivity }\end{array}$ & 50 & $\mathrm{M}$ & Gelhar et al. [1992] \\
Molecular diffusion coefficient & $8.64 \times 10^{-6}$ & $\mathrm{~m}^{2} \mathrm{day}^{-1}$ & Yang et al. [2013] \\
$\begin{array}{l}\text { Freshwater density } \\
\text { Seawater density }\end{array}$ & 1000 & $\mathrm{Kg} \mathrm{m}^{-3}$ & \\
$\begin{array}{l}\text { Freshwater concentration } \\
\text { Seawater concentration }\end{array}$ & 1025.5 & $\mathrm{Kg} \mathrm{m}^{-3}$ & \\
$\begin{array}{l}\text { Manning roughness coefficient } \\
\text { (land) }\end{array}$ & 35 & $\mathrm{~g} \mathrm{~L}^{-1}$ & \\
$\begin{array}{l}\text { Manning roughness coefficient } \\
\text { (beach) }\end{array}$ & $1 \times 10^{-7}$ & $\mathrm{~g} \mathrm{~L}^{-1}$ & \\
\hline
\end{tabular}




\section{Figures}

(a)

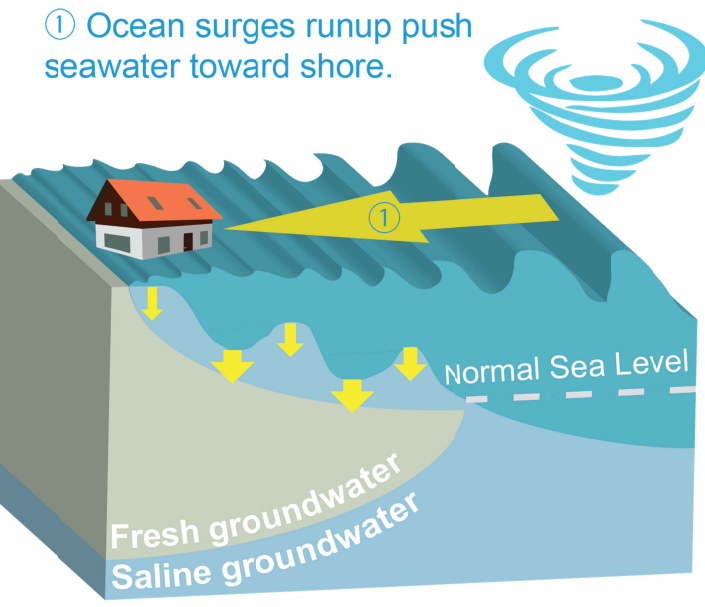

(c)

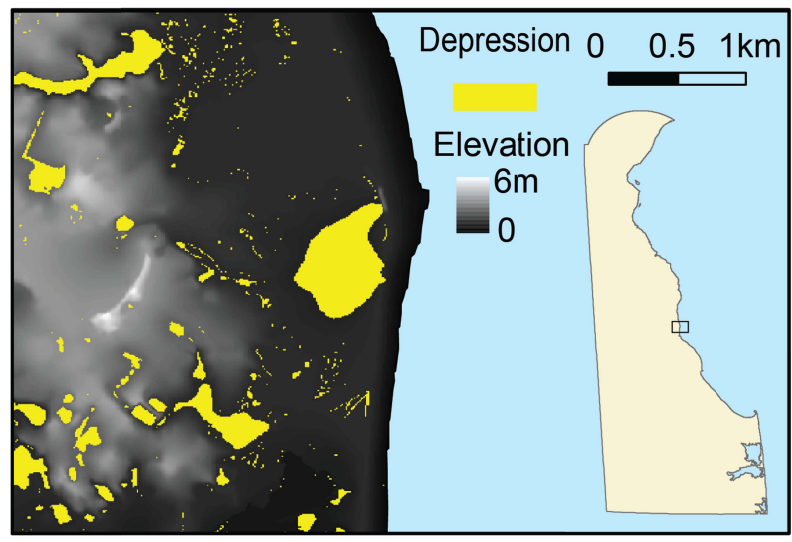

(b)

(2) Topographic depressions prolong infiltration time.

(3) Connectedness affects rundown process.

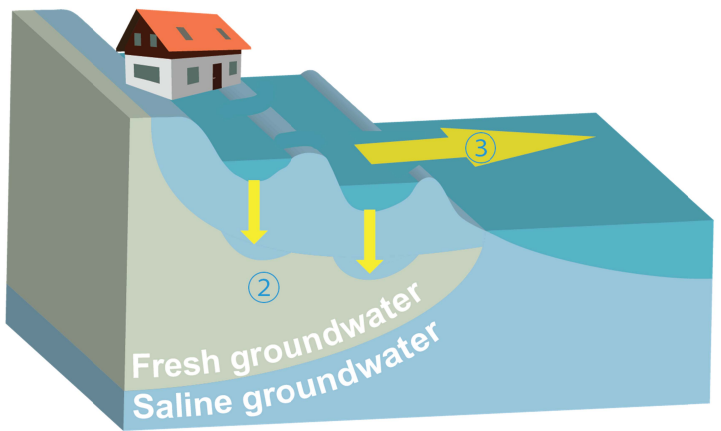

(d)

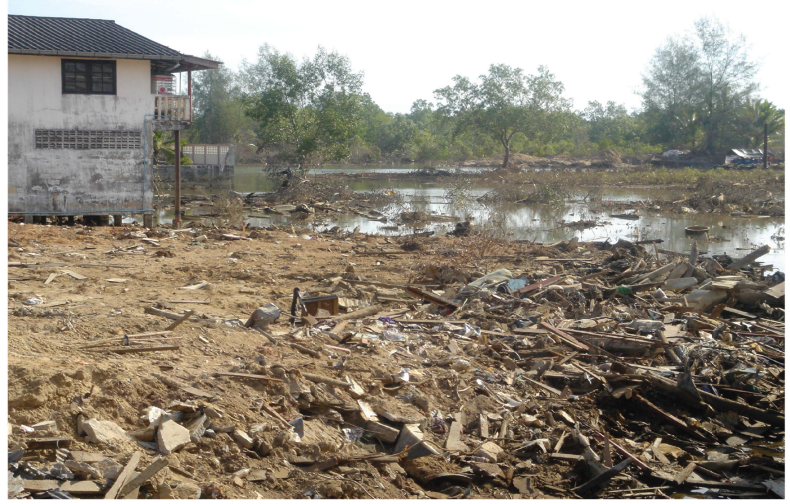

Figure 1. Schematic illustration of the ocean surge-introduced saltwater infiltration at the surface of a coastal aquifer. (a) Surface water inundation introduces salt to surficial coastal aquifers during ocean surge runup. Topography affects the temporal and spatial dynamics of runup, which causes spatial variation in seawater infiltration. (b) Topographic depressions prolong the infiltration processes after the surge, and the connectedness of low-elevation topography affects the spatial and temporal dynamics of the rundown process. (c) An example elevation map of 10 $\mathrm{m}$ DEM in Delaware, USA with identified topographic depressions (in yellow color). The topographic depression is an area that is lower in elevation than its surroundings, which can be identified by the fill function of ArcMap [Environmental systems research institute, 2011] Spatial Analyst tools. (d) Photo of saltwater pools in coastal Thailand one month after the 2004 Indian Ocean tsunami (photo credit: H. Michael).

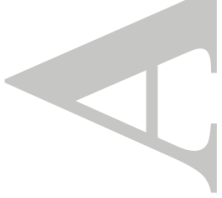


Net precipitation $(X \geq 500 \mathrm{~m})$

Flux $=0.3 \mathrm{~m} /$ year $\left(7.2 \times 10^{3} \mathrm{~m}^{3}\right.$ day $\left.^{-1}\right)$

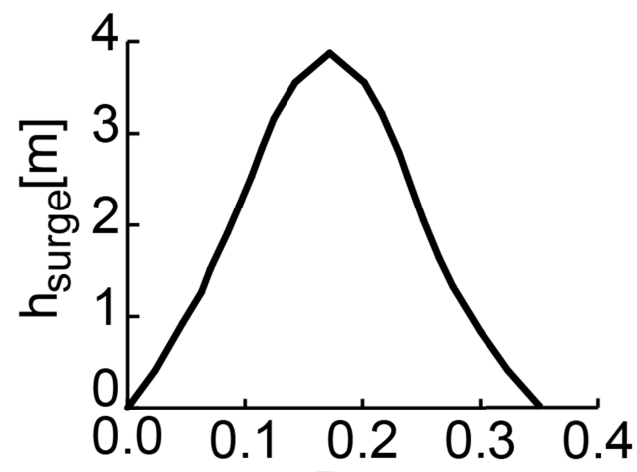

$x_{Y^{\prime}}$
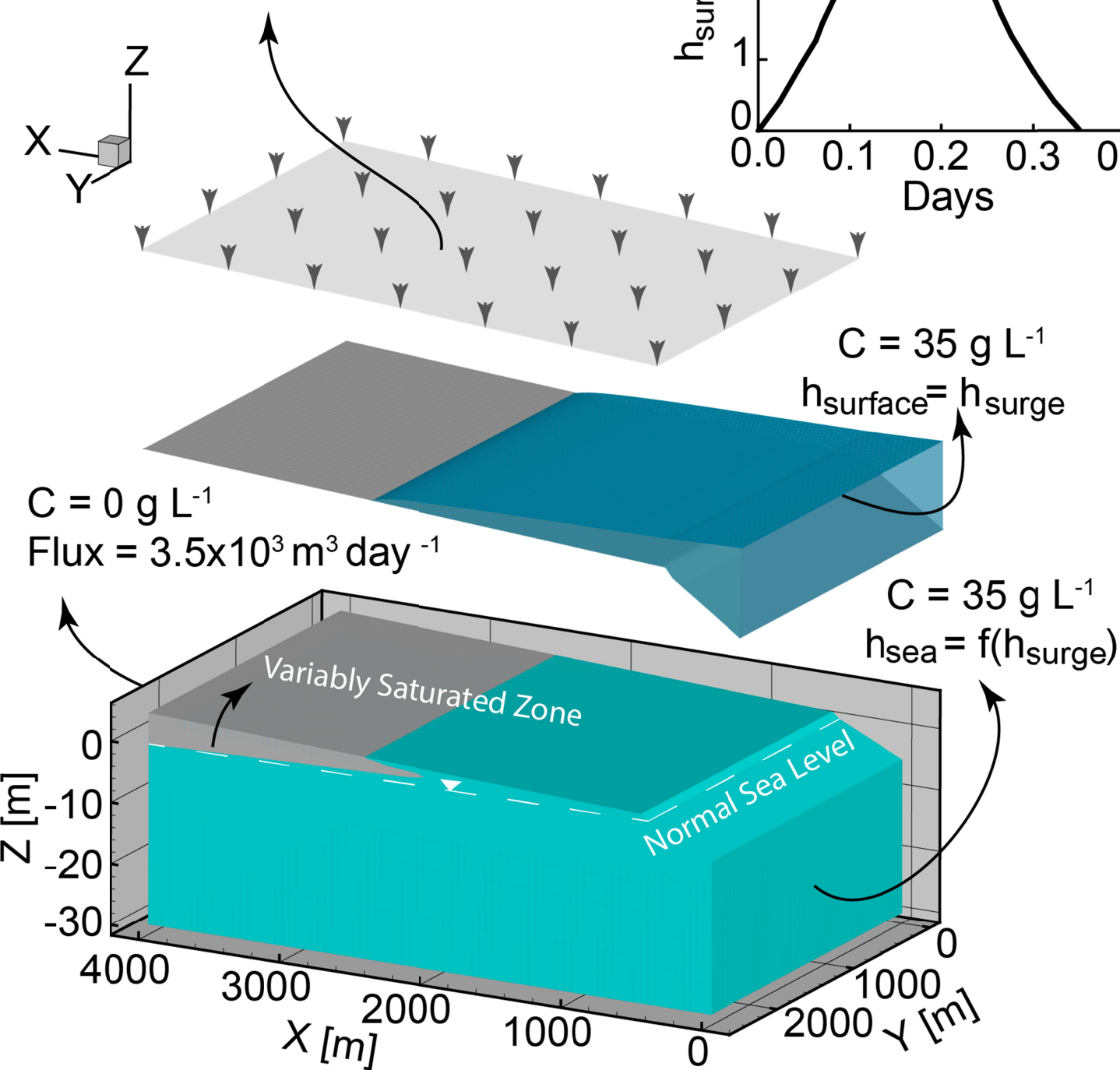

r $r \quad$ Days

Figure 2. Schematic diagram of problem geometry. The diagram shows an unconfined aquifer extending offshore with coupled surface water domain on its top. Dark blue in the surface domain indicates seawater, teal indicates the saturated zone in the subsurface domain. White dashed line indicates the position of the water table before the ocean surge. During the runup of ocean surge, surface seawater is moving landward, and seawater quickly saturates the vadose zone near the coast, while a discrete infiltration front is formed at the inundation line.

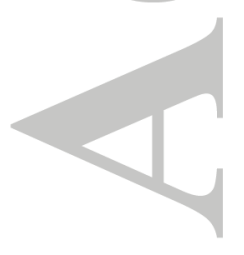




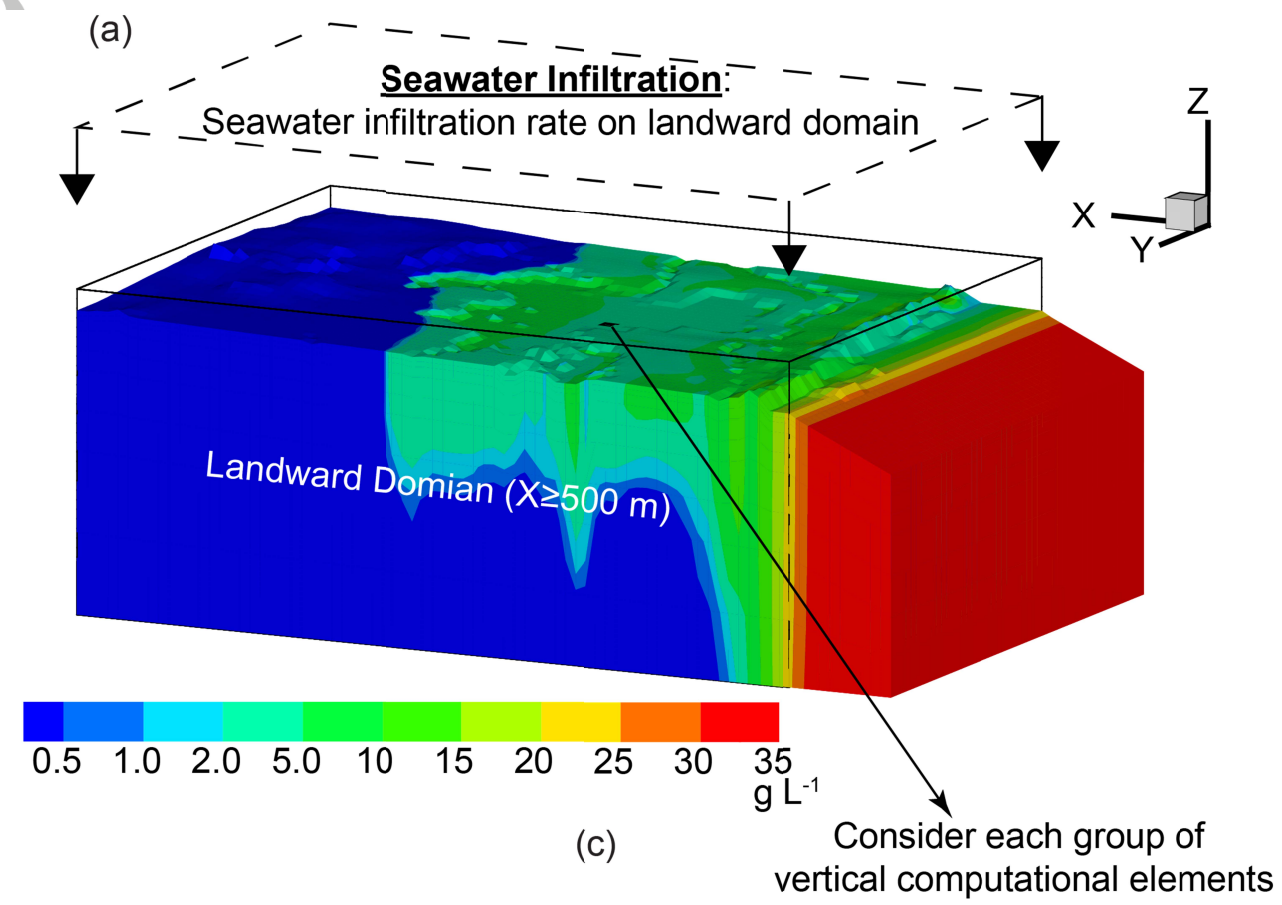

(b)

Flushing Time:Time for recovery of salinized aquifer

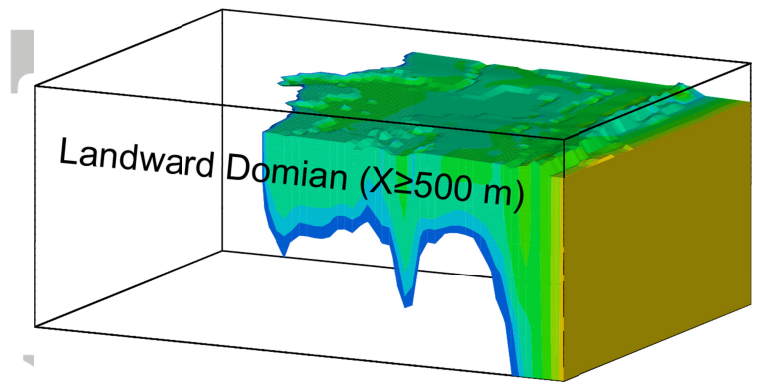

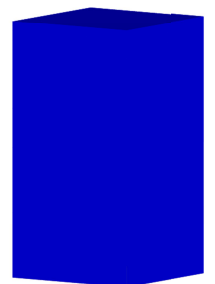

$\mathrm{T}_{0}:$ Storm begins

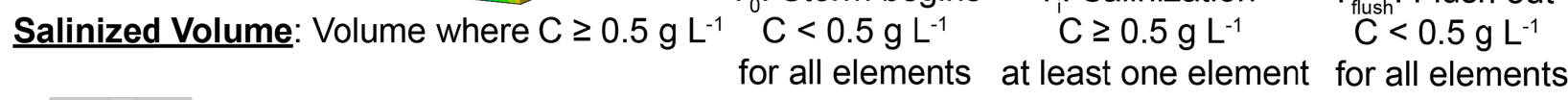

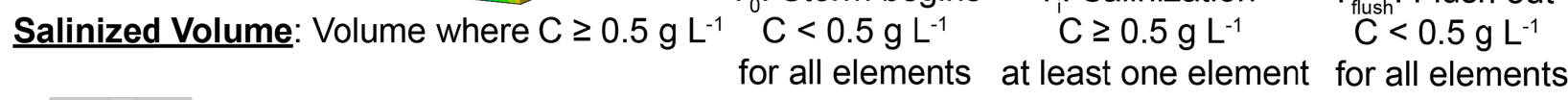

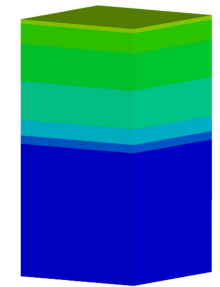

$T_{i}:$ Salinization

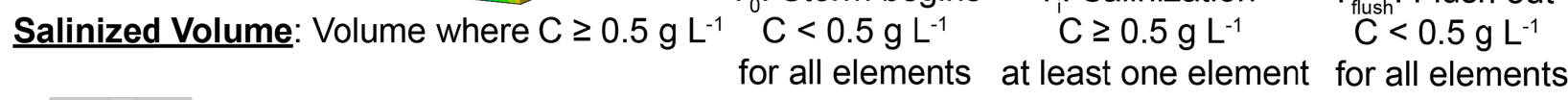

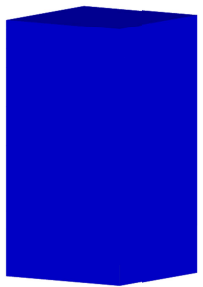

$\mathrm{T}_{\text {flush }}$ : Flush out

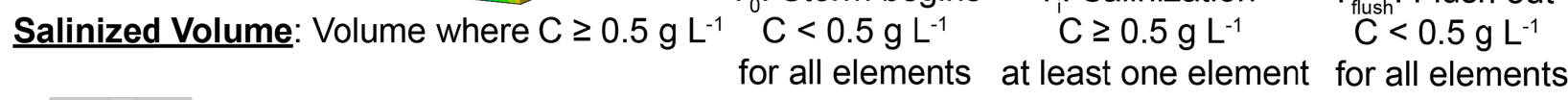

Figure 3. The groundwater salinization assessment criteria include (a) seawater infiltration, (b) salinized volume, and (c) flushing time. Seawater infiltration is assessed as time-dependent flux and cumulative amount. Salinized volume is assessed as time-dependent salinized volume and the maximum salinized volume. Flushing time is assessed as a spatial variable at each lateral model location. Transient simulation results of Normalized Real Case 4 are used to demonstrate the criteria. 


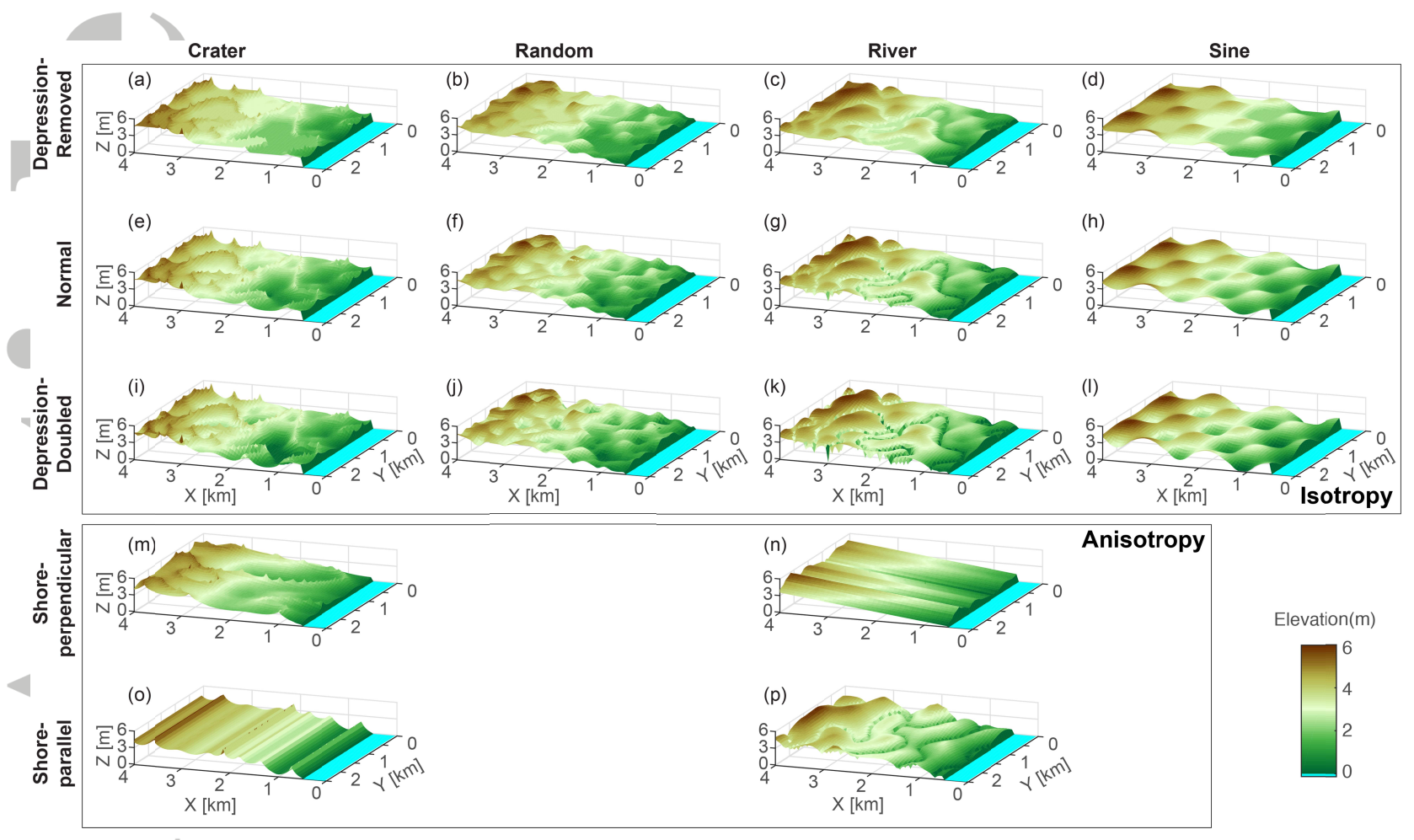

Figure 4. Synthetic topography of 16 types. The upper box (a-1) includes four isotropic topography categories: crater, random, river, and sine. Each category has three depression scenarios: depression removed (a-d), normal (e-h) and depression doubled (i-l). Crater, random and river categories have five realizations by varying the statistical seed. Sine category has five realizations that differ in phase. The lower box (m-p) includes four types of anisotropic topography: shore-perpendicular of crater (m), shore-parallel of crater (n), shore-perpendicular of river (o), and shore-parallel of river (p). Each type has five statistically equivalent realizations generated by varying the statistical seeds. The color gradient shows the elevation. The uniform blue color shows the normal sea level at 0 meter. 

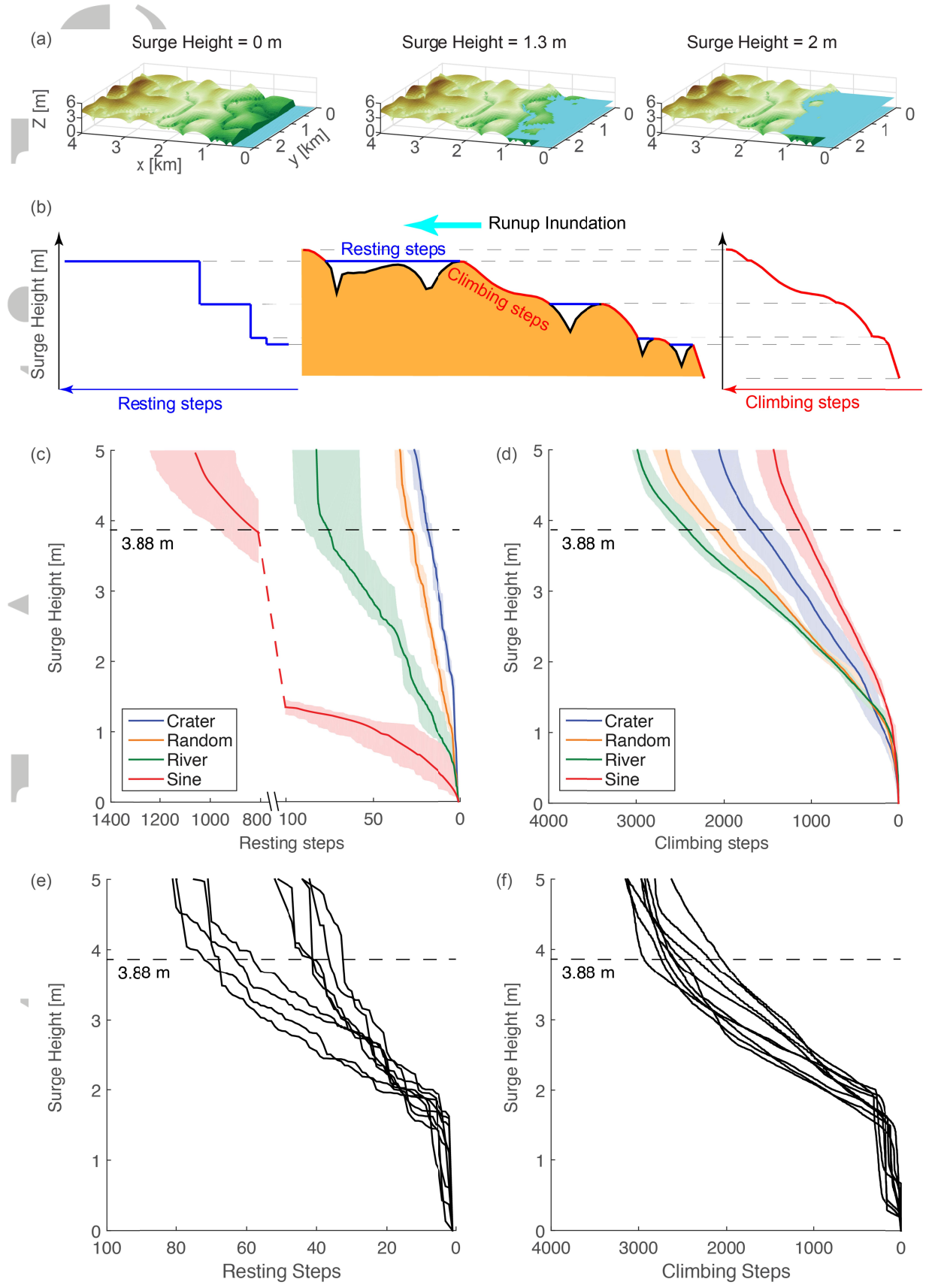

Figure 5. Calculation of climbing and testing steps. (a) Application of the flood fill algorithm on a River-type topography to obtain the inundation process during ocean surge runup. (b) $2 \mathrm{D}$ view of flood fill algorithm (middle column) and the process of extracting two connectivity indicators: resting steps (left column) and climbing steps (right column). (c) Resting steps of the four synthetic topographical types: Crater, Random, River, and Sine. Note the x-axis is broken due to the higher order of magnitude of resting steps in Sine type. (d) Climbing steps of the four synthetic topographical types: Crater, Random, River, and Sine. The mean values are shown by lines and the filled envelopes are limited by the 1st and 9th deciles. (e) Resting steps of 9 cases of Normalized Real topography. (f) Climbing steps of 9 cases of Normalized Real topography. 
(a)

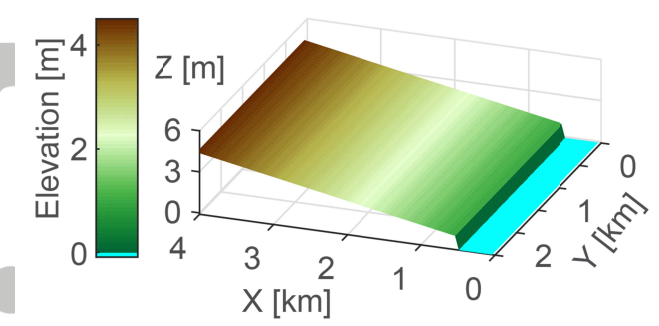

(c)

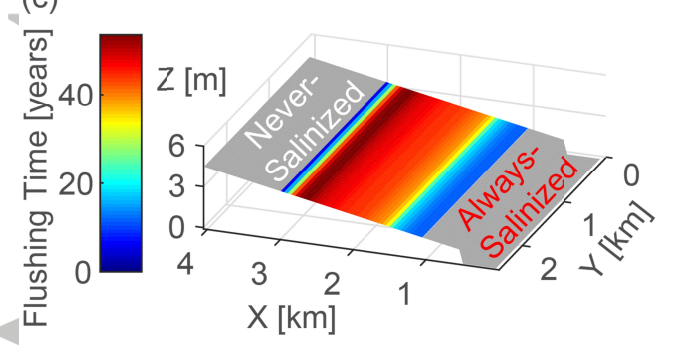

(b)

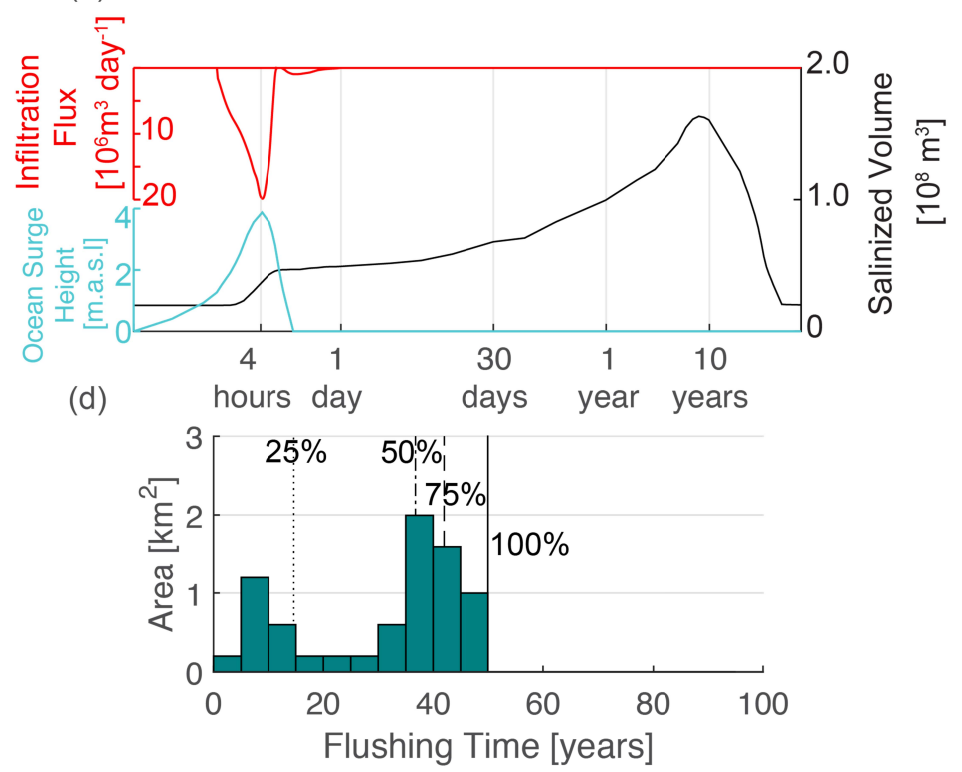

Figure 6. Groundwater salinization assessment for the base case. (a) Topography, (b) ocean surge height (blue), infiltration flux (red), and salinized volume (black), (c) spatial variation of flushing time across the landscape (representative of the column of aquifer below each location), and (d) flushing time distribution. The vertical lines in (d) indicate the 25th, 50th, 75th, and 100th percentiles.

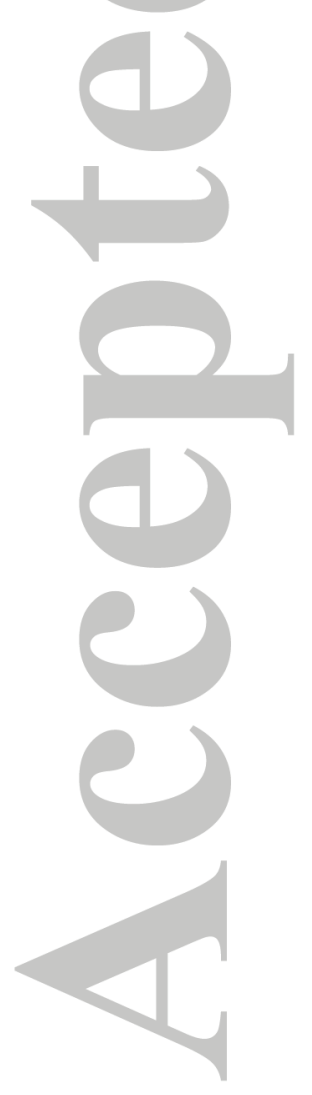


- Crater - Random $\diamond$ River $\Delta$ Sine $\bigcirc$ Depression-removed O Normal $\bullet$ Depression-doubled
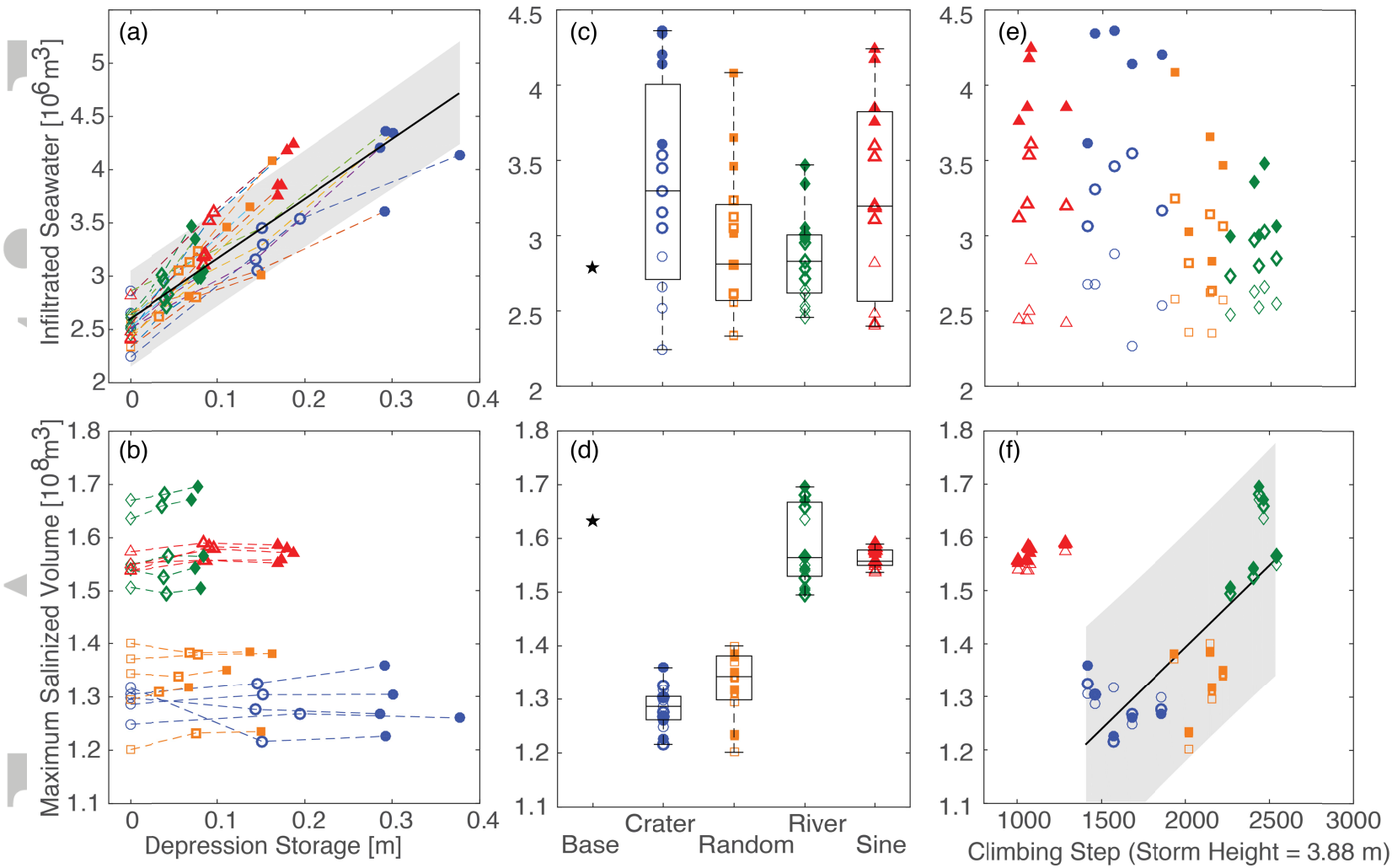

Figure 7. Infiltrated seawater and maximum salinized volume of synthetic topography. (a) Scatterplot of depression storage and infiltrated seawater. (b) Scatterplot of depression storage and maximum salinized volume. In (a) and (b), the dashed line connects depression-removed, normal, and depression-doubled cases for each realization. (c) Ranges of infiltrated seawater in each topography type. (d) Ranges of maximum salinized volume in each topography type. In (c) and (d), the star-shape dots indicate the values of base case. (e) Scatterplot of climbing steps and depression storage. (f) Scatterplot of climbing steps and maximum salinized volume. In (a) and (f), the black line is a linear regression, and the gray area indicates the $95 \%$ confidence interval. 

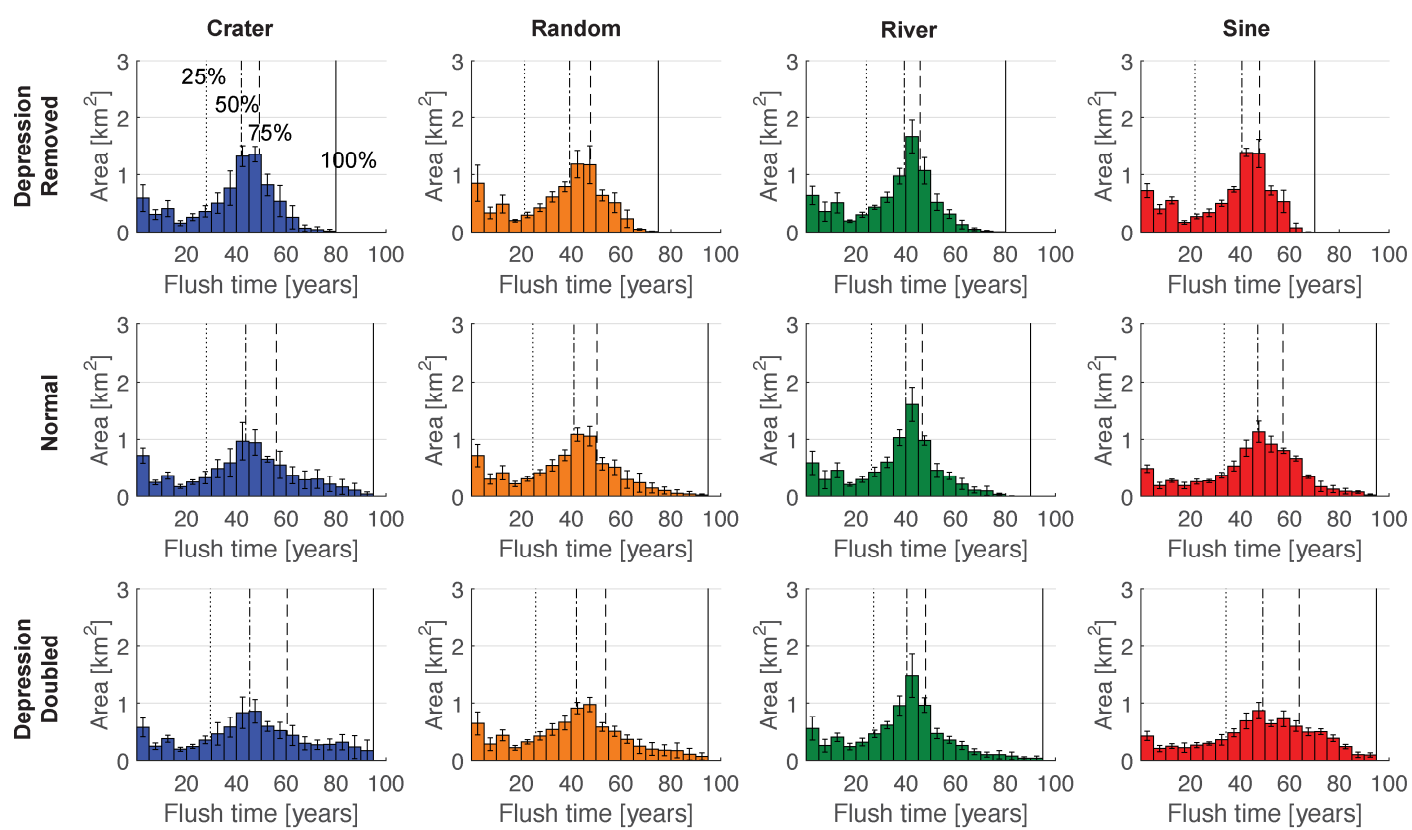

Figure 8. Flushing time distributions for synthetic topography simulations. The distributions are averaged over the five realizations for each type. The error bars represent the standard deviations. The vertical lines indicate the 25 th, 50 th, 75 th, and 100 th percentiles.

This article is protected by copvright. All rights reserved. 
(a)

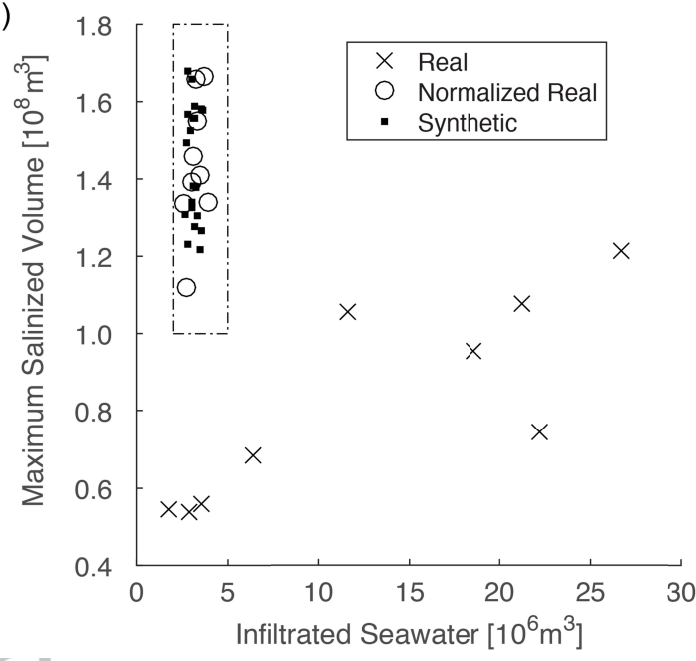

(b)

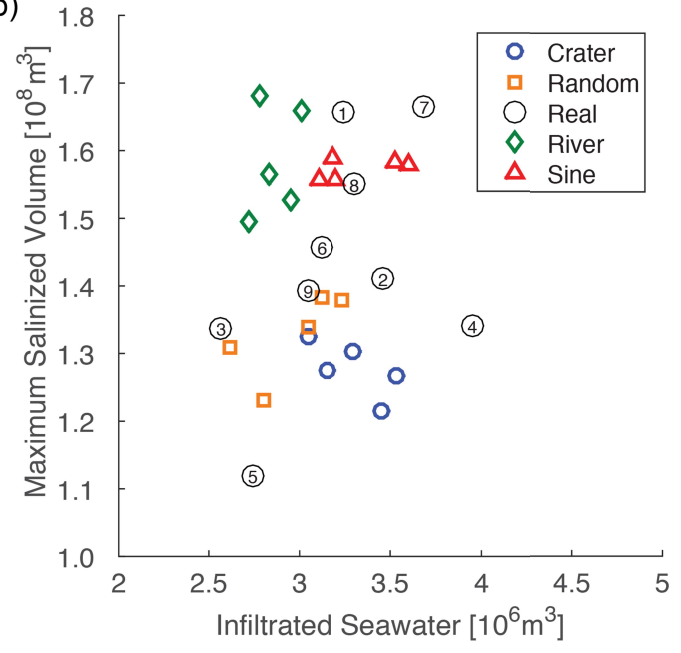

Figure 9. Comparison of simulation results for real-world and synthetic coastal topographies. The extent of (b) corresponds to the dotted box in (a). Please note only normal (i.e. depressionremoved and depression-doubled cases are excluded) cases of synthetic topography are presented.
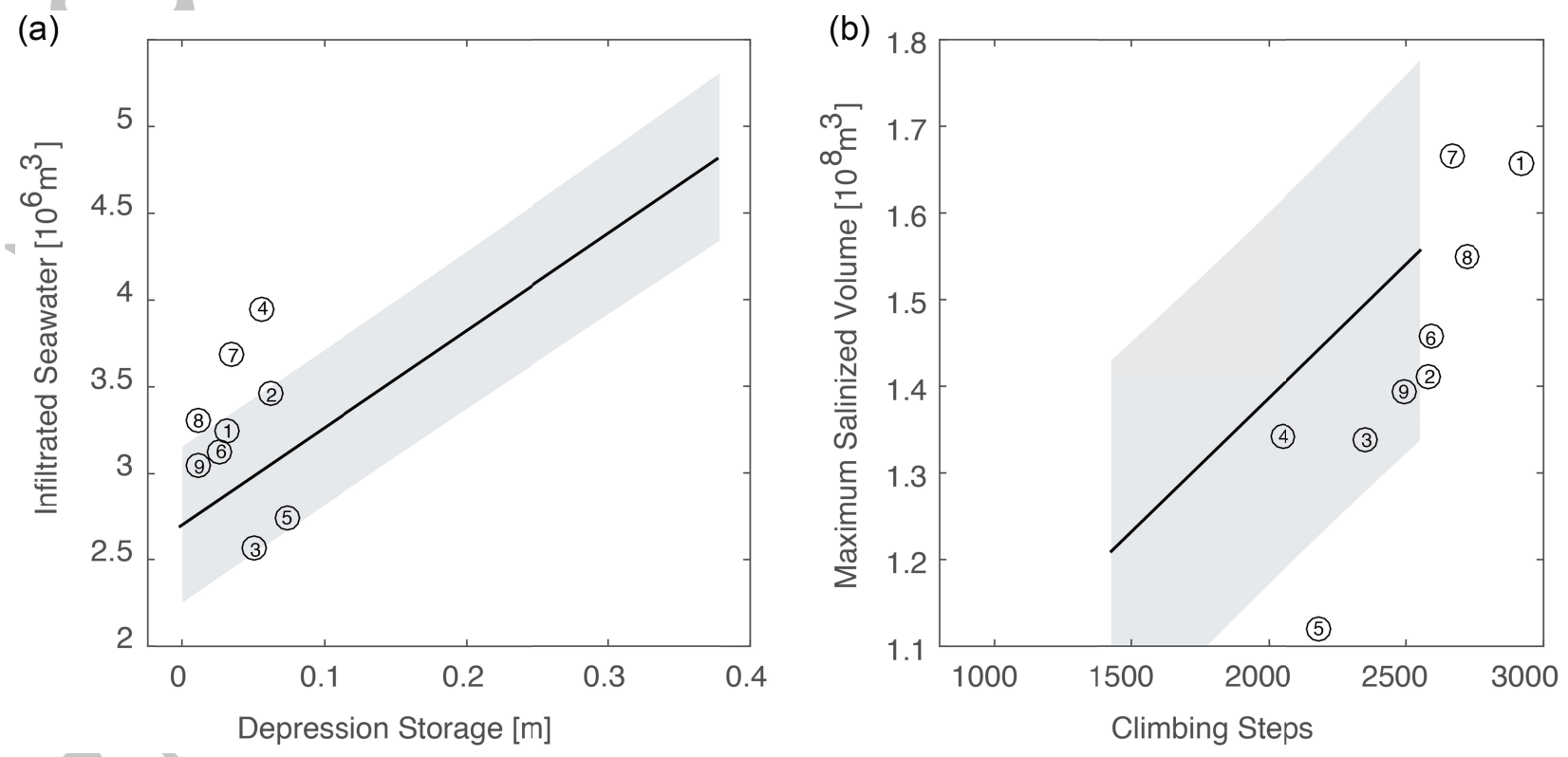

Figure 10. Indication capability of depression storage and climbing steps on Normalized Real topography. (a) Scatterplot of depression storage and infiltrated seawater. The black line and gray area is from Figure 7(a) for comparison. (b) Scatterplot of climbing steps (storm height $=3.88 \mathrm{~m}$ ) and maximum salinized volume. The black line and gray area is from Figure 7(f) for comparison. 

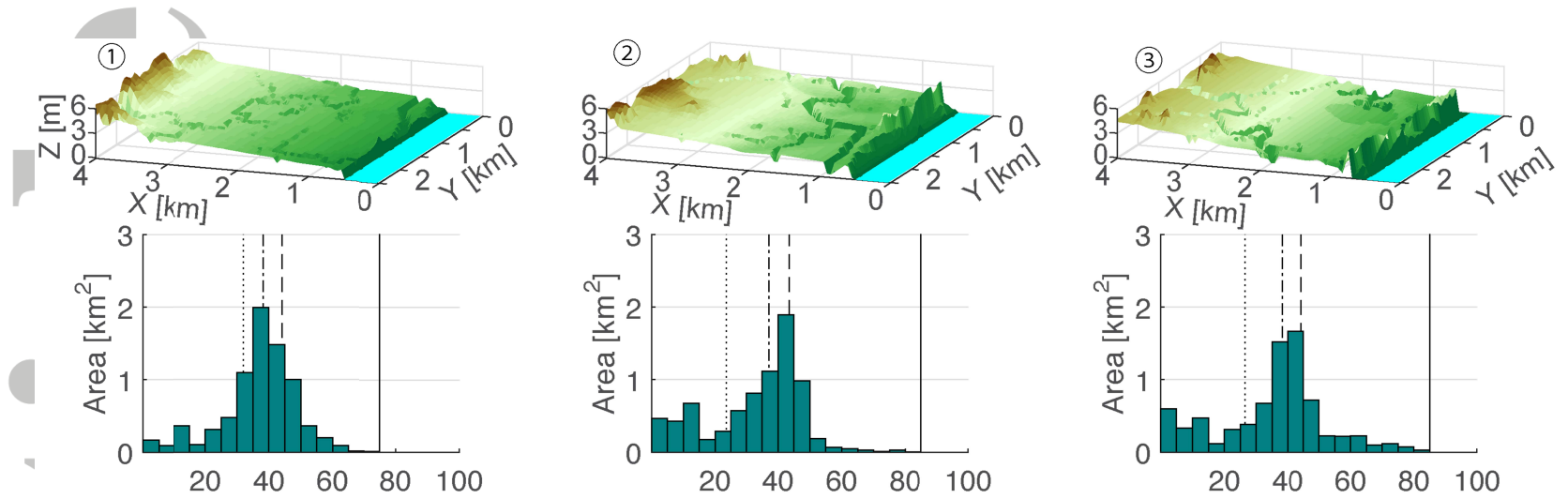

(4)
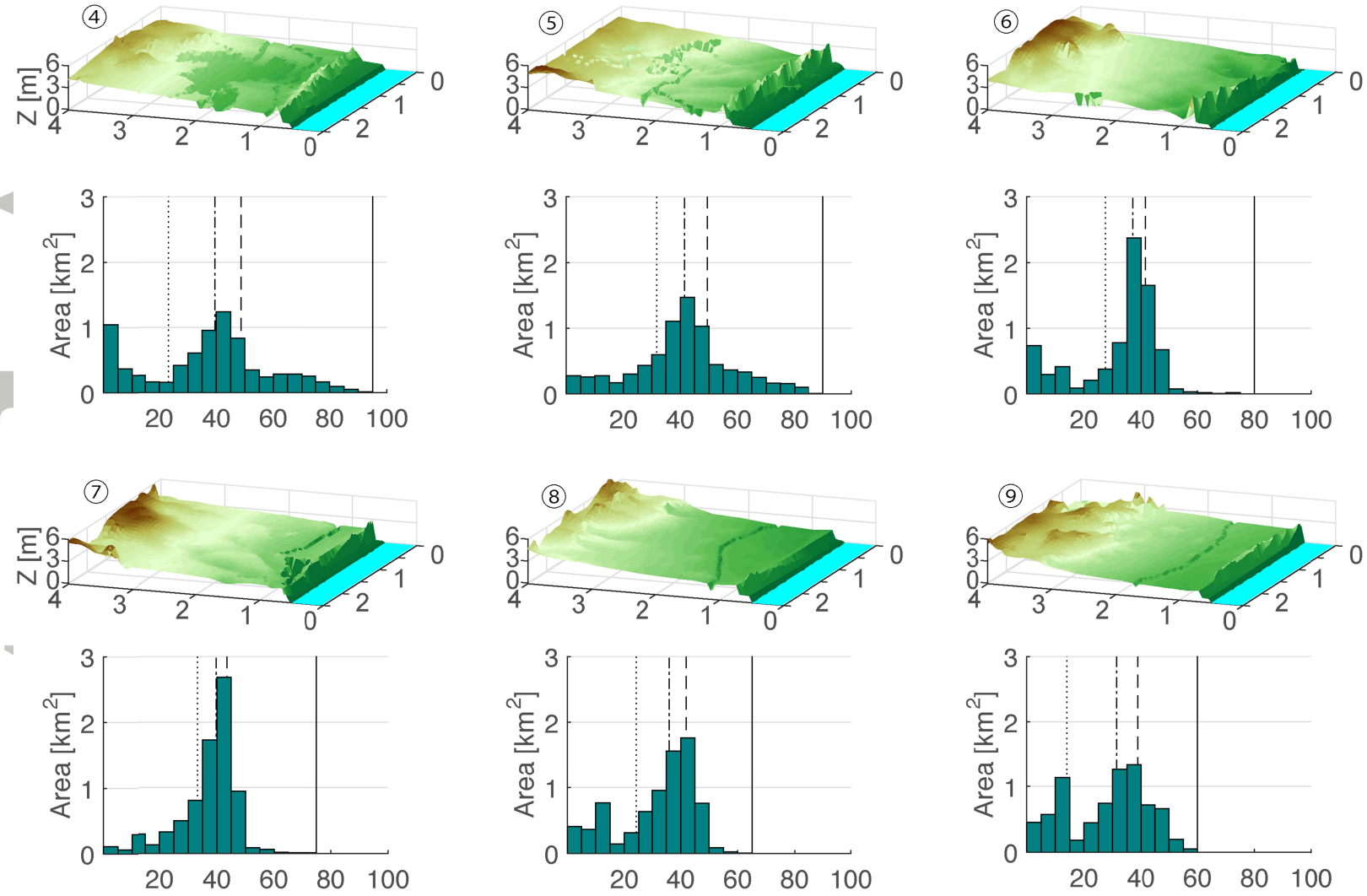

Flushing time [years]

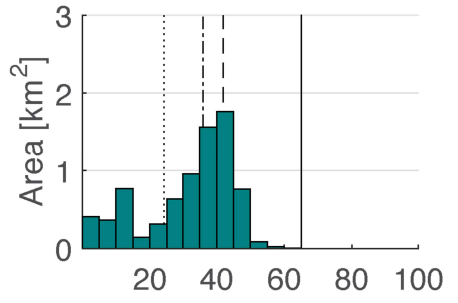

Flushing time [years]

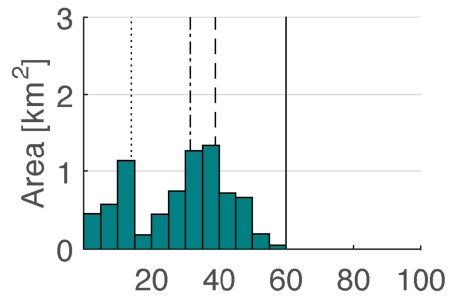

Flushing time [years]

Figure 11. Normalized Real topography and associated flushing time distributions. Vertical lines indicate the 25th, 50th, 75th, and 100th percentiles. 

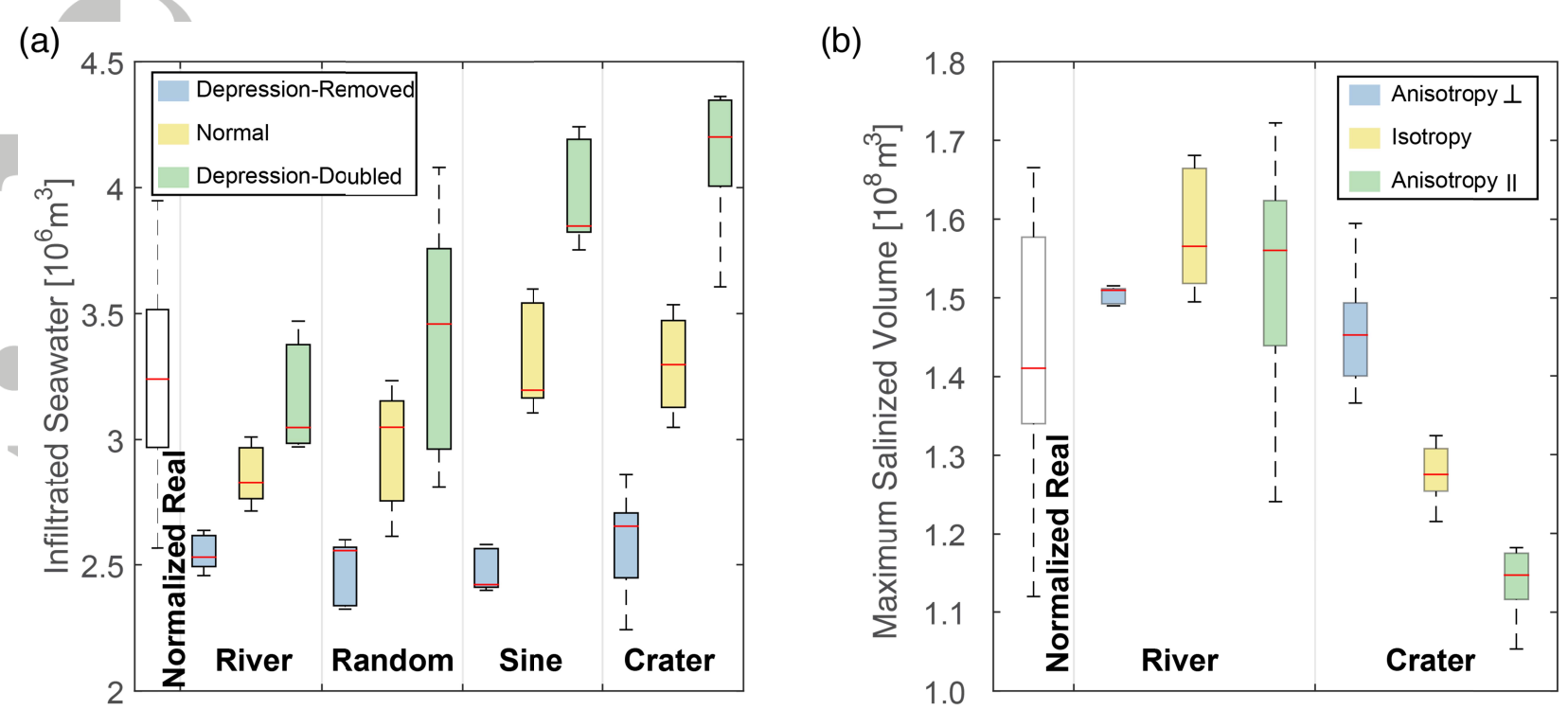

Figure 12. Ranges of infiltrated seawater and maximum salinized volume. (a) Boxplot of infiltrated seawater for each topographic type with depression-double, normal, and depressiondoubled cases. (b) Boxplot of maximum salinized volume for two extreme topographic types (i.e. River and Crater) with different directional characteristic.

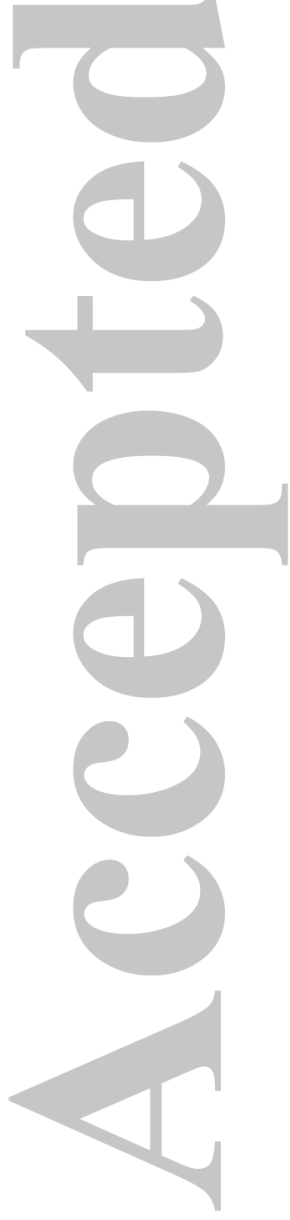

